\title{
Recurrent Fusion of the Genes for High-mobility Group AT-hook 2 (HMGA2) and Nuclear Receptor Co-repressor 2 (NCOR2) in Osteoclastic Giant Cell-rich Tumors of Bone
}

\author{
IOANNIS PANAGOPOULOS ${ }^{1}$, KRISTIN ANDERSEN ${ }^{1}$, LUDMILA GORUNOVA ${ }^{1}$, \\ MARIUS LUND-IVERSEN ${ }^{2}$, INGVILD LOBMAIER $^{2}$ and SVERRE HEIM ${ }^{1,3}$ \\ ${ }^{1}$ Section for Cancer Cytogenetics, Institute for Cancer Genetics and Informatics, \\ The Norwegian Radium Hospital, Oslo University Hospital, Oslo, Norway; \\ ${ }^{2}$ Department of Pathology, The Norwegian Radium Hospital, Oslo University Hospital, Oslo, Norway; \\ ${ }^{3}$ Institute of Clinical Medicine, Faculty of Medicine, University of Oslo, Oslo, Norway
}

\begin{abstract}
Background/Aim: Chimeras involving the highmobility group AT-hook 2 gene (HMGA2 in 12q14.3) have been found in lipomas and other benign mesenchymal tumors. We report here a fusion of HMGA2 with the nuclear receptor co-repressor 2 gene (NCOR2 in 12q24.31) repeatedly found in tumors of bone and the first cytogenetic investigation of this fusion. Materials and Methods: Six osteoclastic giant cell-rich tumors were investigated using G-banding, RNA sequencing, reverse transcription polymerase chain reaction, Sanger sequencing, and fluorescence in situ hybridization. Results: Four tumors had structural chromosomal aberrations of $12 q$. The pathogenic variant c.103_104GG>AT (p.Gly35Met) in the H3.3 histone A gene was found in a tumor without $12 q$ aberration. Inframe HMGA2-NCOR2 fusion transcripts were found in all tumors. In two cases, the presence of an HMGA2-NCOR2 fusion gene was confirmed by FISH on metaphase spreads. Conclusion: Our results demonstrate that a subset of osteoclastic giant cell-rich tumors of bone are characterized by an HMGA2-NCOR2 fusion gene.
\end{abstract}

This article is freely accessible online.

Correspondence to: Ioannis Panagopoulos, Section for Cancer Cytogenetics, Institute for Cancer Genetics and Informatics, The Norwegian Radium Hospital, Oslo University Hospital, Montebello, PO Box 4954 Nydalen, NO-0424 Oslo, Norway. Tel: +47 22782362, email: ioannis.panagopoulos@rr-research.no

Key Words: Benign bone tumor, non-ossifying fibroma, giant cell tumor of bone, osteoclastic giant cell-rich tumors of bone, cytogenetics, chromosomal aberrations, HMGA2, NCOR2, $H M G A 2-N C O R 2$ fusion gene.
According to the latest edition of the World Health Organization classification of soft tissue and bone tumors, published in 2020, aneurysmal bone cyst, non-ossifying fibroma, and giant cell tumor of bone comprise a group of osteoclastic giant cell-rich tumors $(1,2)$. Their common feature is that they contain reactive osteoclast-type multinucleated giant cells $(1,2)$.

Aneurysmal bone cysts are pathogenetically characterized by rearrangements of chromosome band $17 \mathrm{p} 13$ targeting the ubiquitin-specific protease 6 gene (USP6 or Tre2) resulting in fusions in which USP6 is the 3 ' moiety, but where the promoter of USP6 is replaced by a stronger promoter from the partner fusion gene so that USP6 becomes transcriptionally up-regulated (3-8). The chromosome translocation $\mathrm{t}(16 ; 17)(\mathrm{q} 22 ; \mathrm{p} 13)$ is the most frequent cytogenetic aberration reported $(21 \%)$ in aneurysmal bone cysts with an abnormal karyotype (9). It generates a fusion gene in which the strong promoter of the cadherin 11 gene (CDH11) from 16q21 fuses with the USP6 coding sequence from $17 \mathrm{p} 13(6,7)$ leading to a $C D H 11-U S P 6$ chimera in which the USP6 gene is transcriptionally up-regulated $(3,4)$.

In non-ossifying fibromas, activating mutations in the mitogen-activated protein kinase pathway were recently found in $81 \%$ of examined tumors $(10,11)$. Using DNA sequencing methodology, mutually exclusive pathogenic mutations were identified in the KRAS proto-oncogene (in $12 \mathrm{p} 12)$, fibroblast growth factor receptor 1 gene (FGFRl in $8 \mathrm{p} 11)$, and neurofibromin 1 gene $(N F 1$ in 17q11) $(10,11)$. Giant cell tumors of bone are genetically characterized by pathogenic variations in the 35th codon (exon 2) of the H3.3 histone A gene $(H 3-3 A$ alias H3F3A) (12-20). The pathogenic variation c.103G >T, p.Gly35Trp (NM_002107.4, NP_002098.1, COSM1732355) is found in most giant cell tumors, where it is detected only in cells with a fibroblast- 
Table I. Clinicopathological data on the tumors with high-mobility group AT-hook 2 and nuclear receptor co-repressor 2 genes (HMGA2-NCOR2) fusion.

\begin{tabular}{|c|c|c|c|c|c|c|}
\hline Case & $\begin{array}{l}\text { Gender/age, } \\
\text { years }\end{array}$ & Diagnosis & $\begin{array}{l}\text { Pathogenic variation } \\
\text { in exon } 2 \text { of } H 3-3 A\end{array}$ & $\begin{array}{l}\text { Tumor } \\
\text { location }\end{array}$ & $\begin{array}{l}\text { Fusion } \\
\text { transcript }\end{array}$ & Karyotype \\
\hline 1 & $\mathrm{~F} / 37$ & $\begin{array}{l}\text { Benign fibrous } \\
\text { histiocytoma }\end{array}$ & None & TH9 vertebra & $\begin{array}{l}\text { HMGA2ex3- } \\
\text { NCOR2 } \mathrm{ex} 16\end{array}$ & $\begin{array}{l}46, \mathrm{XX}, ? \operatorname{add}(12)(\mathrm{q} 24), \operatorname{del}(20)(\mathrm{q} 11)[11] / \\
\quad 47 \sim 49, \mathrm{XX},+7,+18[\mathrm{cp} 5] / 46, \mathrm{XX}[4]\end{array}$ \\
\hline 2 & $\mathrm{~F} / 40$ & $\begin{array}{l}\text { Benign fibrous } \\
\text { histiocytoma }\end{array}$ & None & Os pubis & $\begin{array}{l}\text { HMGA2ex4- } \\
\text { NCORex } 16\end{array}$ & $\begin{array}{c}46, X X, \operatorname{der}(6)(6 \mathrm{pter}->6 \mathrm{q} 21:: 12 \mathrm{q} 13-> \\
12 \mathrm{q} ?:: ?:: 12 \mathrm{q} 24->12 \mathrm{q} 14:) \\
\operatorname{add}(12)(\mathrm{q} 13)[7] / 46, \mathrm{XX}[10]\end{array}$ \\
\hline 3 & $\mathrm{M} / 36$ & $\begin{array}{l}\text { Giant cell tumor of } \\
\text { bone with components } \\
\text { of secondary } \\
\text { aneurysmal bone cyst }\end{array}$ & None & Distal tibia & $\begin{array}{l}\text { HMGA2ex4- } \\
\text { NCOR2 } \mathrm{e} 16\end{array}$ & $\begin{array}{c}46, \mathrm{XY}, \mathrm{t}(12 ; 12)(\mathrm{q} 13 \sim 15 ; \mathrm{q} 24) \\
{[9] / 46, \mathrm{XY}[3]}\end{array}$ \\
\hline 4 & $\mathrm{~F} / 16$ & $\begin{array}{l}\text { Giant-cell tumor of } \\
\text { bone after treatment } \\
\text { with denosumab }\end{array}$ & None & Scapula & $\begin{array}{l}\text { HMGA2 } \mathrm{ex} 4- \\
\text { NCOR2 } \mathrm{ex} 16\end{array}$ & $\begin{array}{c}\text { 46,XX,der(2)(2pter->2q37::12q24-> } \\
\text { 12q14:),del(12)(q14 15)[5]/47,idem,+17 } \\
\text { [3]/46,idem,add(17)(q25)[3]/46,XX[2] }\end{array}$ \\
\hline $\begin{array}{l}5 \mathrm{a} \\
5 \mathrm{~b} \\
5 \mathrm{c}\end{array}$ & $\mathrm{M} / 20$ & $\begin{array}{l}\text { Giant cell tumor of } \\
\text { bone with components } \\
\text { of secondary } \\
\text { aneurysmal bone cyst }\end{array}$ & $\begin{array}{l}\text { c.103_104GG> } \\
\text { AT (p.Gly35Met) }\end{array}$ & $\begin{array}{l}\text { Distal left } \\
\text { femur }\end{array}$ & $\begin{array}{l}\text { HMGA2 } \mathrm{e} 4- \\
\text { NCOR2ex } 16\end{array}$ & $\begin{array}{c}\text { a: } 45, X Y,-4[6] / 46, i d e m,+r[c p 13] / 46, X Y[2] \\
\text { b: } 46, X Y,-4,+r[5] / 46, X Y[7] \\
\text { c: } 46 \sim 47, X Y,-4,+r[c p 9] / 46, X Y[2]\end{array}$ \\
\hline $\begin{array}{l}6 \mathrm{a} \\
6 \mathrm{~b}\end{array}$ & $\mathrm{M} / 21$ & Giant cell tumor of bone & None & L5 vertebra & $\begin{array}{l}\text { HMGA2 } \mathrm{e} 3- \\
\text { NCOR } 2 \mathrm{ex} 16\end{array}$ & $\begin{array}{l}\text { a: } 46, X Y \\
\text { b: } 46, X Y\end{array}$ \\
\hline
\end{tabular}

F: Female; M: male. All samples were negative for immunohistochemistry against H3.3 G35W.

like appearance, not in giant cells or their precursors (12-18). Other mutations found in the same codon of $H 3-3 A$ are p.Gly35Leu, p.Gly35Val, p.Gly35Met, p.Gly35Glu, and p.Gly35Arg (12-18). Giant cell tumors of bone without mutation in $H 3-3 A$ have also been reported $(13,14)$.

In the present study, we describe six osteoclastic giant cell-rich tumors that carried a fusion between the genes coding for high-mobility group AT-hook 2 (HMGA2) and nuclear receptor co-repressor 2 (NCOR2).

\section{Materials and Methods}

Ethics statement. The study was approved by the Regional Ethics Committee (Regional komité for medisinsk forskningsetikk Sør-Øst, Norge, http://helseforskning.etikkom.no). All clinical information has been de-identified.

Tumor description. Table I shows the patients' gender, age, diagnosis, and tumor location. The patients were three males and three females. The age range was from 16 to 40 years with a median of 28.5 years. The tumors in patients 1 and 2 were diagnosed as benign fibrous histiocytoma of bone. In patients 3 to 6 , the tumors were diagnosed as giant cell tumor of bone. Immunohistochemistry showed that all tumors were negative for H3.3 G35W (previously written as G34W).

Patient 1 was a 37-year-old woman with back pain for 2 years and neurological symptoms. A tumor in the TH9 vertebra was found with computed tomography. Core-needle biopsy showed a fibrous lesion in the bone, with macrophages and scattered giant cells. The diagnosis was benign fibrous histiocytoma of bone (Figure 1A). The lesion was H3.3 G35W IHC-negative (Figure 1B). Examination of the curetted specimen confirmed the diagnosis.
Patient 2 was a 40-year-old woman. The tumor was located in the pubic bone. It was H3.3 G35W IHC-negative and diagnosed as a benign fibrous histiocytoma of bone.

The tumors of patients 3 and 5 were located in the distal tibia and distal femur, respectively. They were diagnosed as giant cell tumors of bone with components of aneurysmal bone cyst.

Patient 4 was a 16-year-old girl. She had had shoulder pain for 9 months. An expansive lesion in the scapula with bone destruction was found. Examination of a core-needle biopsy showed tumor tissue with scattered giant cells against a background of blandlooking mononuclear cells, scattered macrophages, and hemosiderin deposits (Figure 1C). Despite negative IHC analysis for H3.3 G35W (Figure 1D), a diagnosis of giant cell tumor of bone was reached and the patient received denosumab for 4 months followed by curettage. The histological picture of fibrous tumor tissue with mononuclear cells and scattered giant cells (Figure 1C) was consistent with the diagnosis of a giant cell tumor.

In patient 6 , a tumor was found in the L5 vertebra. Although it was H3.3 G35W IHC-negative, a diagnosis of giant cell tumor of bone was reached.

$G$-Banding and karyotyping. The methods used to investigate the tumors cytogenetically were described elsewhere (21). Briefly, a part of resected tumor was minced with scalpels into 1-2 mm fragments and then enzymatically disaggregated with collagenase II (Worthington, Freehold, NJ, USA). The resulting cells were cultured, harvested, and processed for cytogenetic examination using standard techniques (22). A G-banding pattern of chromosomes was obtained using Wright's stain (Sigma-Aldrich, St Louis, MO, USA) (22). Metaphases were analyzed and karyograms prepared using the CytoVision computerassisted karyotyping system (Leica Biosystems, Newcastle upon Tyne, UK). The karyotypes were described according to the International System for Human Cytogenomic Nomenclature (23). 
A

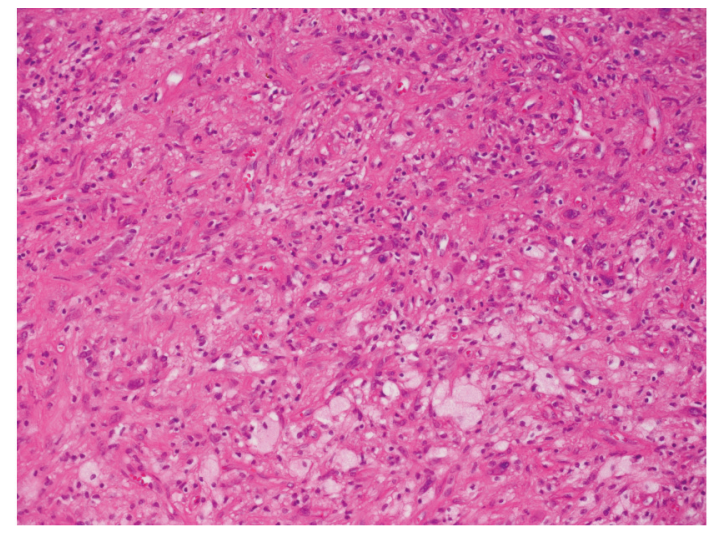

\section{C}

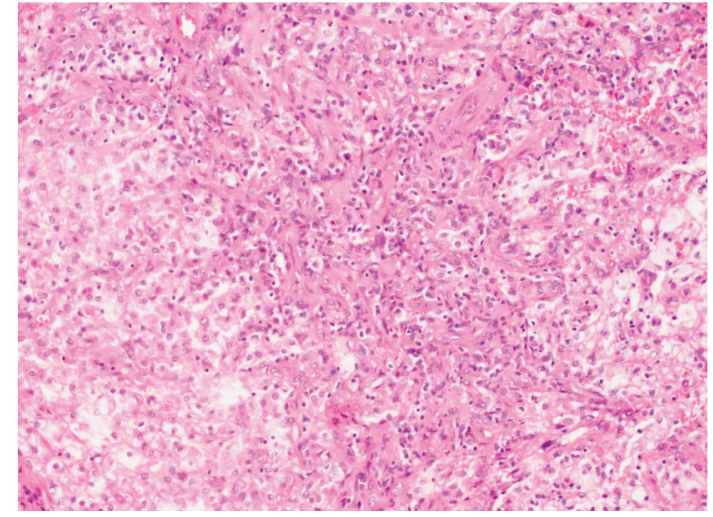

B

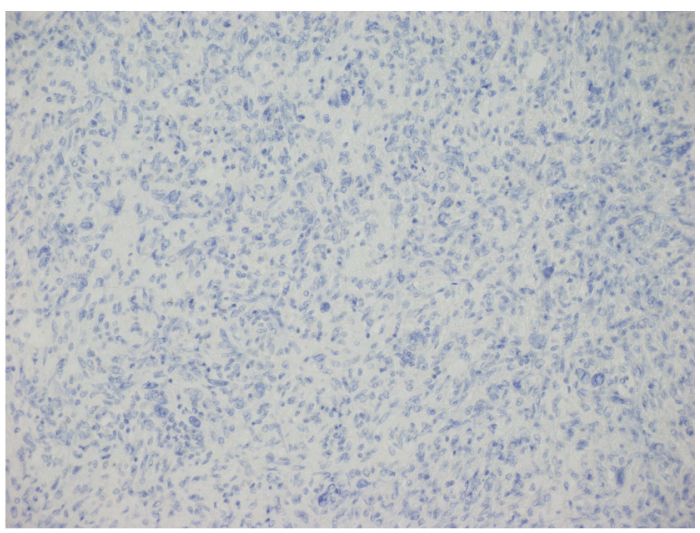

D

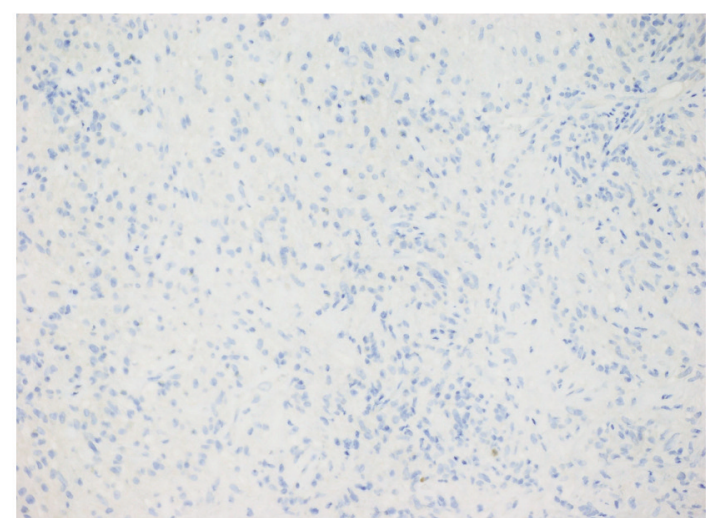

Figure 1. Microscopic examination of osteoclastic giant cell-rich tumor of bone from case 1 ( $A$ and $B)$ and case $4(C$ and $D)$. A: The tumor tissue consisted of mononuclear cells with eosinophilic cytoplasm and small, round to oval nuclei. Throughout the tumor tissue there were scattered areas of foamy macrophages and a few multinuclear giant cells (the latter not visible in the image), hematoxylin and eosin (H\&E), $\times 20$ objective. B: Immunohistochemical examination against $\mathrm{H3} .3 \mathrm{G} 35 \mathrm{~W}$ (previously written as $\mathrm{G} 34 \mathrm{~W}$ ) showing cell nuclei within the tumor tissue that were negative for H3.3 G35W. C: The histological picture was dominated by mononuclear cells without atypia. The nuclei were round to oval, and the cytoplasm had indistinct borders. Throughout the lesion there were areas with foamy macrophages. Very few giant cells were seen, H\&E, $\times 20$ objective. D: Immunohistochemical examination showed that nuclei in the tumor tissue were negative for $\mathrm{H} 3.3 \mathrm{G} 35 \mathrm{~W}$.

Sanger sequencing for detection of pathogenic variation in exon 2 of the H3-3A gene. Genomic DNA from tumor samples was extracted using a Maxwell RSC Instrument and a Maxwell RSC Tissue DNA Kit (Promega, Madison, WI, USA) and subsequently quantified with Quantus Fluorometer and the QuantiFluor ONE dsDNA System (Promega). Extracted DNA (100-150 ng) was used as polymerase chain reaction (PCR) template for detection of possible pathogenic variation in exon 2 of the H3-3A gene (NCBI reference sequence: NM_002107.4). The primers M13For-H3F3AEx2-F2 and M13Rev-H3F3A-Ex2-R2 (Table II), together with the BigDye Direct Cycle Sequencing Kit, were used to perform both PCR and cycle (Sanger) sequencing according to the company's recommendations (ThermoFisher Scientific, Waltham, MA, USA) The sequences obtained by Sanger sequencing were compared with the NCBI reference sequence NM_002107.4.

RNA sequencing. Total RNA was extracted from frozen tumor tissue adjacent to that used for cytogenetic analysis and histological examination using miRNeasy Mini Kit (Qiagen, Hilden, Germany).
RNA sequencing was performed on cases 1 and 2 (Table I). For this purpose, $1 \mu \mathrm{g}$ of total RNA was sent to the Genomics Core Facility at the Norwegian Radium Hospital, Oslo University Hospital for high-throughput paired-end RNA sequencing. A total of $89 \times 10^{6}$ and $107 \times 10^{6} 76$-bp-length reads were obtained from the tumors of cases 1 and 2, respectively. FASTQC software was used for quality control of the raw sequence data (available online at: http://www. bioinformatics.babraham.ac.uk/projects/fastqc/). Fusion transcripts were found using FusionCatcher software $(24,25)$. The "grep" command was also used to search the fastq files of the sequence data for the HMGA2-NCOR2 fusion sequence. The principle of this approach has been described in detail elsewhere (26-28). The search terms were "AGGAAATGGCAGCAGCAA" and "AGGAAATGGC AGCAACAA" for case 1 and "CCTGCTCAGCAGCAGCAA" and "CCTGCTCAGCAGCAACAA" for case 2.

Reverse transcription (RT)PCR and Sanger sequencing analyses. The primers used for PCR amplification and Sanger sequencing analyses are shown in Table II. The methodologies for cDNA 
Table II. Primers used for polymerase chain reaction amplification and Sanger sequencing analyses. M13 forward primer (TGTAAAACGACGGCCAGT) and M13 reverse primer (CAGGAAACAGCTATGACC) sequences are shown in italics.

\begin{tabular}{|c|c|c|c|}
\hline Gene name (gene symbol) & Name: Sequence $\left(5^{\prime}->3^{\prime}\right)$ & $\begin{array}{l}\text { Reference sequence: } \\
\text { Position }\end{array}$ & Chr. band \\
\hline $\mathrm{H} 3.3$ histone $\mathrm{A}(H 3-3 A)$ & $\begin{array}{l}\text { M13For-H3F3A-Ex2-F2: TGTAAAACGACGGCCAGT- } \\
\text { CAGGAAAAGTTGTATGTTTGGTAGTTGC }\end{array}$ & $\begin{array}{c}\text { NC_000001.11: } 226,064 \\
\text { 268-226,064,295 }\end{array}$ & $1 \mathrm{q} 42.12$ \\
\hline $\mathrm{H} 3.3$ histone $\mathrm{A}(H 3-3 A)$ & $\begin{array}{c}\text { M13Rev-H3F3A-Ex2-R2: CAGGAAACAGCTATGACC- } \\
\text { AAAGCAAAAAGTTTTCCTGTTATCCATC }\end{array}$ & $\begin{array}{c}\text { NC_000001.11: } 226,064 \\
547-226,064,574\end{array}$ & $1 \mathrm{q} 42.12$ \\
\hline High mobility group AT-hook 2 (HMGA2) & $\begin{array}{l}\text { HMGA2-846F1: CCACTTCAGCCC } \\
\text { AGGGACAACCT }\end{array}$ & NM_003483.4: 846-868 & $12 \mathrm{q} 14.3$ \\
\hline High mobility group AT-hook 2 (HMGA2) & $\begin{array}{c}\text { HMGA2-925F1: ACCAACCGGTGA } \\
\text { GCCCTCTCCTA }\end{array}$ & NM_003483.4: 925-947 & $12 \mathrm{q} 14.3$ \\
\hline Nuclear receptor co-repressor $2($ NCOR 2$)$ & $\begin{array}{l}\text { NCOR2-2076R1: CTTCCTTGTCGT } \\
\text { TCTCCACCTCCG }\end{array}$ & NM_006312.6: 2099-2076 & $12 \mathrm{q} 24.31$ \\
\hline Nuclear receptor co-repressor $2(N C O R 2)$ & $\begin{array}{l}\text { NCOR2-2127R1: TCGTCGTTG } \\
\text { TCCTCCCCTGAGG }\end{array}$ & NM_006312.6: 2148-2127 & $12 \mathrm{q} 24.31$ \\
\hline
\end{tabular}

Chr: Chromosomal.

Table III. BAC probes used for fluorescence in situ hybridization experiments in order to detect the high-mobility group AT-hook 2 and nuclear receptor co-repressor 2 (HMGA2-NCOR2) fusion gene. The positions of the HMGA2 and NCOR2 genes are also given.

\begin{tabular}{|c|c|c|c|c|c|}
\hline BAC clone & $\begin{array}{c}\text { Accession } \\
\text { number }\end{array}$ & $\begin{array}{c}\mathrm{Chr} \\
\text { mapping }\end{array}$ & $\begin{array}{l}\text { Targeted } \\
\text { gene }\end{array}$ & $\begin{array}{l}\text { Position on GRCh38/ } \\
\text { hg38 assembly }\end{array}$ & Labelling \\
\hline RP11-185K16 & AQ418927.1 and AQ418930.1 & $12 q 14.3$ & $H M G A 2$ & Chr12:65427017-65594623 & Fluorescein-12-dCTP (Green) \\
\hline RP11-30I11 & B87811.1 and B87812.1 & $12 \mathrm{q} 14.3$ & $H M G A 2$ & Chr12:65498459-65669659 & Fluorescein-12-dCTP (Green) \\
\hline \multirow[t]{2}{*}{ RP11-662 G15 } & AQ411650 and AQ411760 & $12 q 14.3$ & $H M G A 2$ & Chr12:65608717-65818177 & \multirow[t]{2}{*}{ Fluorescein-12-dCTP (Green) } \\
\hline & NM_003483.6 & $12 \mathrm{q} 14.3$ & $H M G A 2$ & Chr12:65824483-65966291 & \\
\hline RP11-118B13 & $\begin{array}{c}\mathrm{AQ} 347872.1, \mathrm{AQ} 347869.1 \\
\text { and } \mathrm{AC} 135255.2\end{array}$ & $12 \mathrm{q} 14.3$ & $H M G A 2$ & Chr12:65964922-66109206 & Fluorescein-12-dCTP (Green) \\
\hline RP11-745O10 & AC078927.20 & $12 q 14.3$ & $H M G A 2$ & Chr12:66083023-66208799 & Fluorescein-12-dCTP (Green) \\
\hline RP11-263A04 & AC025603.1 & $12 \mathrm{q} 14.3$ & $H M G A 2$ & Chr12:66246378-66412442 & Fluorescein-12-dCTP (Green) \\
\hline RP11-522N14 & AC026358.36 & $12 q 24.31$ & NCOR2 & Chr12:124142622-124286745 & Texas Red-5-dCTP (Red) \\
\hline \multirow[t]{2}{*}{ RP11-408I18 } & AC073916.41 & $12 \mathrm{q} 24.31$ & NCOR2 & Chr12:124286746-124490024 & \multirow[t]{2}{*}{ Texas Red-5-dCTP (Red) } \\
\hline & NM_006312.6 & $12 q 24.31$ & NCOR2 & Chr12:124324415-124495252 & \\
\hline RP11-83B20 & AC073592.11 & $12 q 24.31$ & NCOR2 & Chr12:124499239-124658361 & Texas Red-5-dCTP (Red) \\
\hline
\end{tabular}

Chr: Chromosome.

synthesis, RT-PCR amplification, and Sanger sequencing were described elsewhere $(29,30)$. For the first outer PCR amplification, the primer combination HMGA2-846F1/NCOR2-2127R1 was used. For the second inner PCR, the primer combination HMGA2925F1/NCOR2-2076R1 was used. The Basic Local Alignment Search Tool (BLAST) was used to compare the sequences obtained by Sanger sequencing with the NCBI reference sequences NM_003483.4 (HMGA2) and NM_006312.6 (NCOR2) (31).

Fluorescence in situ hybridization (FISH). For the detection of HMGA2-NCOR2 fusion gene, a homemade double-fusion FISH probe was used. The BAC probes were purchased from the BACPAC Resource Center operated by BACPAC Genomics, Emeryville, CA, USA (https://bacpacresources.org/) (Table III). The probes for HMGA2 were labelled with fluorescein-12-dCTP (PerkinElmer, Boston, MA, USA) to obtain a green signal. The probes for NCOR2 were labelled with Texas Red-5-dCTP (PerkinElmer) to obtain a red signal. Detailed information on the FISH procedure was given elsewhere $(30,32)$. Fluorescent signals were captured and analyzed using the CytoVision system (Leica Biosystems).

\section{Results}

Karyotyping. Cytogenetic examination revealed chromosomal aberrations in five tumors whereas a normal male karyotype was obtained in both samples from case 6 (Table I). The tumors had pseudo- or near-diploid karyotypes. The dominating feature was an aberration of the $\mathrm{q}$ arm of chromosome 12 found in four cases (Table I, Figure 2). In case 1, G-banding analysis detected two cytogenetically unrelated clones: One had the chromosome abnormalities add(12)(q24) and $\operatorname{del}(20)(q 11)$ whereas the second, composite clone had one 

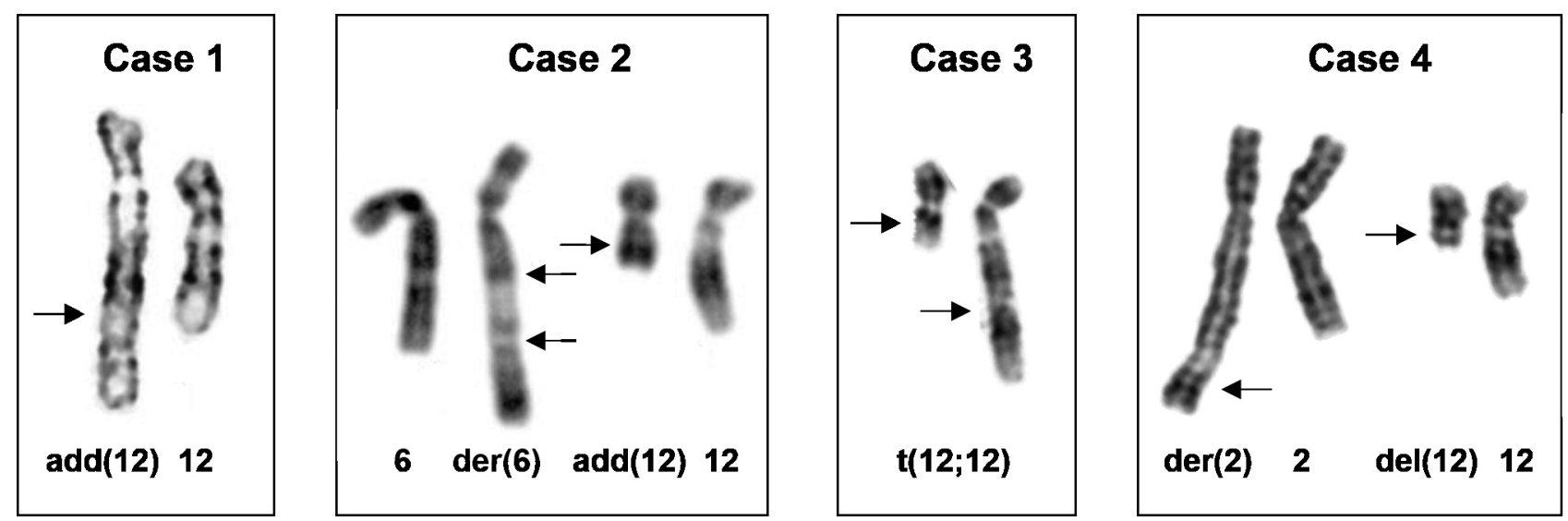

Figure 2. G-Banding analyses of osteoclastic giant cell-rich tumors of bone. Partial karyotypes of tumors (cases 1-4) with 12q anomalies are presented. From case 1, the abnormal chromosome add(12)(q24) together with the normal chromosome 12 are shown. From case 2, the two abnormal chromosomes, der(6)(6pter->6q21::12q13->12q?::?::12q24->12q14:) and add(12)(q13), are shown together with normal chromosomes 6 and 12. From case 3, the two derivative chromosome 12 from the translocation $t(12 ; 12)(q 13 \sim 15 ; q 24)$ are shown. From case 4 , the two abnormal chromosomes, der(2)(2pter$>2 q 37: \because 12 q 24->12 q 14:)$ and del(12)(q14 15), are shown together with the normal chromosomes 2 and 12. Arrows indicate breakpoints.

extra copy of chromosomes 7 and 18. In case 2, a single cytogenetic clone was found with structural aberrations $\operatorname{der}(6)(6 p t e r->6 q 21:: 12 q 13->12 q ?:: ?:: 12 q 24->12 q 14:) \quad$ and $\operatorname{add}(12)(\mathrm{q} 13)$. In the third case, a balanced translocation $\mathrm{t}(12 ; 12)(\mathrm{q} 13 \sim 15 ; \mathrm{q} 24)$ was found as the only abnormality. In the fourth tumor, three related clones were found connected by the presence of a der(2)(2pter->2q37::12q24->12q14:) and a $\operatorname{del}(12)(q 14 \sim 15)$. Finally, the tumor of the fifth case had monosomy 4 and a ring chromosome.

Sanger sequencing of exon 2 of H3-3A. None of the tumors had the pathogenic variation c.103G >T, p.Gly35Trp (NM_002107.4, NP_002098.1, COSM1732355). In the tumor sample from patient 5, the pathogenic variant c.103_104GG>AT (p.Gly35Met) was found (Figure 3).

RNA sequencing. Analysis of the sequencing data with FusionCatcher for case 1 detected an in-frame fusion of exon 3 of HMGA2 from 12q14 (NCBI reference sequences NM_003483.4) with exon 16 of NCOR2 from 12q24 (reference sequence NM_006312.6): AGCCACTGGAGAAAAACGG CCAAGAGGCAGACCTAGGAAATGG*CAGCAGCAACA ACAGCAGCAGCAGCAGCAGCAGCAGCAGCAGC. Examining the fastq files of the sequence data using the "grep" command and the search term "AGGAAATGGCAGCA GCAA", nine sequence reads with the above-mentioned fusion point were found (Table IV), whereas use of the "grep" search with "AGGAAATGGCAGCAACAA" yielded 15 sequence reads with this fusion point. The obtained results agreed with the Sanger sequencing chromatograms, where an AGGAAATGG-CAGCARCAACAR sequence was found at the junction (see below). In case 2, FusionCatcher detected an in-frame fusion of exon 4 of $H M G A 2$ with exon 16 of NCOR2: TAGGAAATGGCCACAACAAGTTGTTCAGAAGAAGCCT GCTCAG*CAGCAGCAACAACAGCAGCAGCAGCAGCA GCAGCAGCAGCAGC. Using the "grep" command and the search term "CCTGCTCAGCAGCAGCAA", 17 sequence reads with the above-mentioned fusion point were found (Table IV), whereas the "grep" search with term "CCTGCTCAGCAG CAACAA" yielded 16 reads with this fusion point. The results agreed with the Sanger sequencing chromatograms which showed an CCTGCTCAG-CAGCARCAACAR sequence at the junction (see below).

Thus, for cases 1 and 2, FusionCatcher, examination of fastq files of sequence data with the "grep" command, and RT-PCR/Sanger sequencing showed that there was an inframe insertion/deletion of a CAG triplet in exon 16 of NCOR2 at the junction of fusion transcripts.

RT-PCR and Sanger sequencing analyses. In cases 1 and 2, RT-PCR with the outer HMGA2-846F1/NCOR2-2127R1 primer combination amplified a 412-bp and a 445-bp cDNA fragment, respectively (Figure 4A). Nested PCR with the inner primer combination HMGA2-925F1/NCOR2-2076R1 amplified 284-bp (case 1) and 317-bp (case 2) cDNA fragments (Figure 4B). Sanger sequencing of the amplified fragments showed that they were HMGA2-NCOR2 chimeric cDNA fragments in which exon 3 of $H M G A 2$ was fused to exon 16 of NCOR2 (case 1) or exon 4 of $H M G A 2$ fused to exon 16 of NCOR2 (case 2) (Figure 4C), thus confirming the results obtained by RNA sequencing.

In cases 3, 4, and 5, nested PCR amplified a 317-bp cDNA fragment (data not shown). Sanger sequencing of these fragments detected fusion between $H M G A 2$ exon 4 and 
Sanger sequencing with forward primer

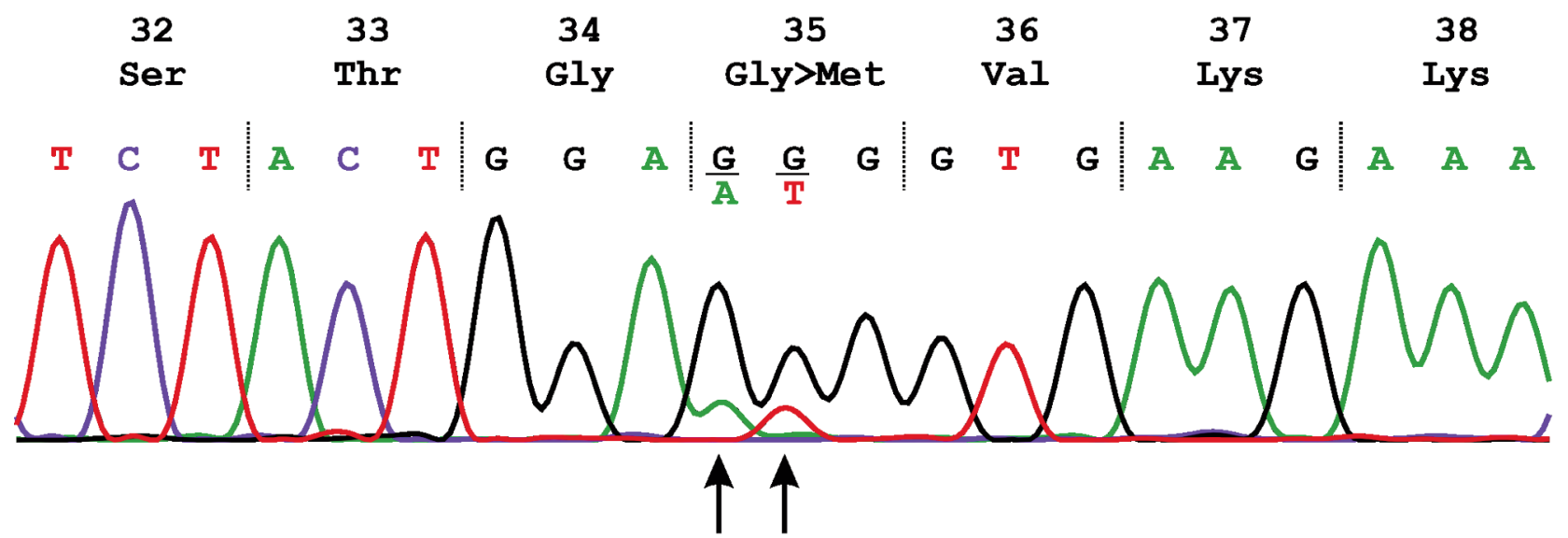

Sanger sequencing with reverse primer

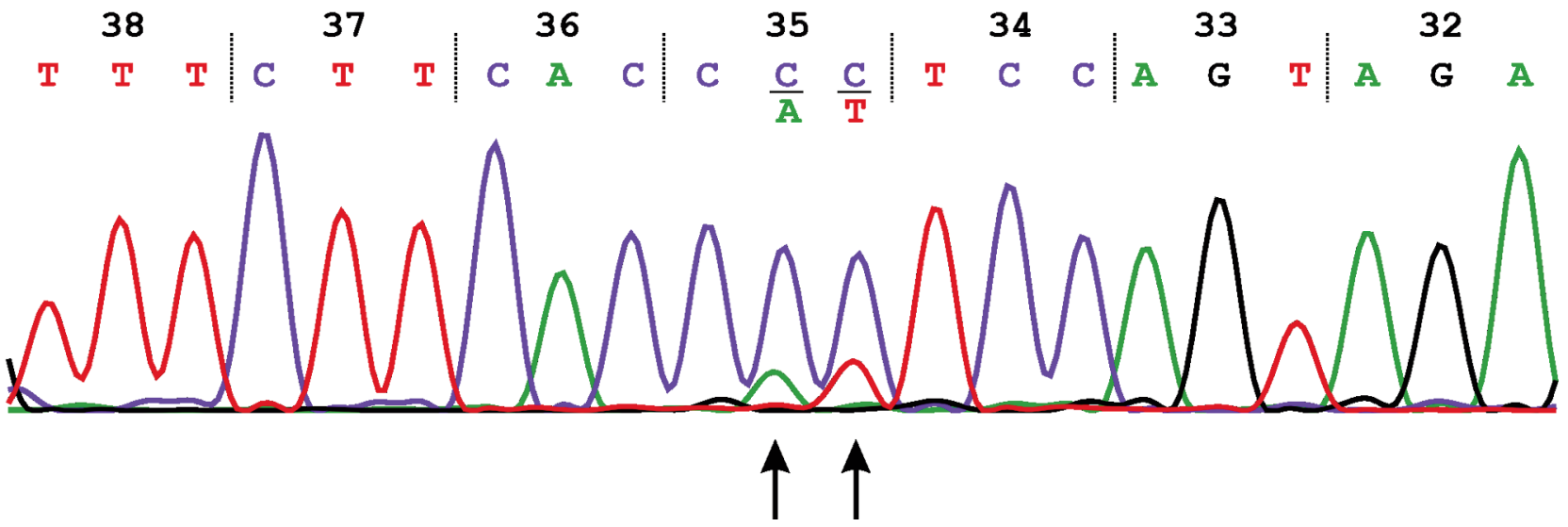

Figure 3. Pathogenic variation in exon 2 of the H3-3A gene. Partial sequence chromatograms of DNA amplified fragments from case 5 showing the presence of the pathogenic variant c.103_104GG $>A T$ (p.Gly35Met) in the tumor.

NCOR2 exon 16 (Table I, Figure 4C). In case 6, nested PCR amplified a 284-bp cDNA fragment in which exon 3 of HMGA2 was fused to exon 16 of NCOR2. At the junction of fusion transcript an in-frame insertion/deletion of a CAG triplet in exon 16 of NCOR2 was found, similar to cases 1 and 2 (Table I, Figure 4C).

FISH analyses. Metaphase spreads from cases 2, 4, and 5 (sample 5c) were available for FISH analysis with a homemade double HMGA2-NCOR2 fusion probe consisting of green-labeled HMGA2 (12q14) and red-labeled NCOR2 probes (12q24) (Table III, Figure 5A). For case 2, a yellow signal for $H M G A 2-N C O R 2$ fusion as well as a green signal for $H M G A 2$ were found on the $\operatorname{der}(6)(6 p t e r->6 q 21:: 12 q 13$ $>12 q$ ?::?::12q24->12q14:) (Figure 5B). Green signals for HMGA2 were seen also on chromosomes 12 and $\operatorname{add}(12)(q 13)$, suggesting the presence of at least one intact (normal) HMGA2 locus in the abnormal metaphases. A red signal for NCOR2 was found on chromosome 12 (Figure 5B).

In case 4, two fusion signals were found on $\operatorname{der}(2)(2$ pter$>2 q 37:: 12 q 24->12 q 14 \sim 15)$ together with a green signal for HMGA2 and a red signal for NCOR2 on chromosome 12 (Figure 5B). In case 5, FISH experiments on metaphase spreads with -4 and $+r$ showed normal patterns, in other words, green (HMGA2) and red (NCOR2) signals on the two chromosomes 12 (Figure 5B).

\section{Discussion}

We describe an HMGA2-NCOR2 fusion transcript found in six osteoclastic giant cell-rich bone tumors in which immunohistochemistry against H3.3 G35W showed that all of them were negative. In one tumor (patient 5), the extremely rare pathogenic variant c.103_104GG>AT (p.Gly35Met) of the 
H3-3A gene was found. This tumor had two cytogenetically unrelated clones: one with monosomy 4 and a ring chromosome with normal patterns for the HMGA2 and NCOR2 genes, the other with an HMGA2-NCOR2 fusion. Thus, we do not know if the p.Gly35Met of the H3-3A gene and HMGA2NCOR 2 fusion occurred in the same clone or not.

In the tumor of cases 1 and 6 , the fusion occurred between exons 3 of $H M G A 2$ and 16 of NCOR2, whereas in the other tumors, exon 4 of $H M G A 2$ was found to be fused to exon 16 of NCOR2. Cytogenetically, four tumors had visible rearrangements of $12 \mathrm{q}$, with one of them (case 3 ) showing a translocation between the two copies of chromosome 12, $\mathrm{t}(12 ; 12)(\mathrm{q} 13 \sim 15 ; \mathrm{q} 24)$. Since HMGA2 (in 12q14) is transcribed from centromere to telomere whereas NCOR2 (in $12 \mathrm{q} 24$ ) is transcribed from telomere to centromere (Figure 4A), neither a simple balanced 12q14;12q24-translocation nor an interstitial deletion $\operatorname{del}(12)(\mathrm{q} 14 \mathrm{q} 24)$ is sufficient to generate the HMGA2-NCOR2 fusion gene. We therefore believe that the seemingly solitary $\mathrm{t}(12 ; 12)(\mathrm{q} 13 \sim 15 ; \mathrm{q} 24)$ of case 3 must be accompanied by additional submicroscopic rearrangement(s), probably an inversion, to enable the generation of a functionally competent HMGA2-NCOR2 fusion on one of the derivative chromosomes 12. A $\mathrm{t}(12 ; 12)(\mathrm{q} 14 ; \mathrm{q} 24)$ was reported in a uterine leiomyoma with a complex karyotype (33).

A paracentric inversion, $\operatorname{inv}(12)(q 14 q 24)$, with break in intron 3 or 4 of $H M G A 2$ and a break upstream of exon 16 of NCOR2, would move part of the 3'-end partner gene NCOR2 from $12 \mathrm{q} 24$ to $12 \mathrm{q} 14$ into the HMGA2 locus where the fusion then takes place. The FISH results from cases 2 and 4 indicate that such an inversion is accompanied by other chromosomal aberrations, including translocations. In case 2 , which had a $\operatorname{der}(6)(6 p t e r->6 q 21:: 12 q 13->12 q ?:: ?:: 12 q 24->12 q 14:)$, the fusion signal (yellow) was proximal whereas a green $H M G A 2$ signal was distal on the der(6). Finally in case 4, a paracentric inversion between $12 \mathrm{q} 14$ and 12q24 chromosomal bands, with breakpoints in the HMGA2 and NCOR2 loci and translocation of this part of chromosome 12 onto a chromosome 2, may explain the finding of a der(2)(2pter->2q37::12q24->12q14:) with two FISH fusion signals on it.

Paracentric inversions inv(12)(q14q24) affecting the $H M G A 2$ gene have been reported in chondroid hamartomas, endometrial polyps, and lipomas (34-39). Fusion of HMGA2 with aldehyde dehydrogenase 2 family member gene $(A L D H 2)$ was also reported, in a uterine leiomyoma, as the result of a cryptic inv(12)(q14q24) (34).

Alternatively, more complex chromosomal aberrations involving double breaks upstream and in intron 3 or 4 of $H M G A 2$ together with breaks in the 5'-end region of NCOR2 would generate an HMGA2-NCOR2 fusion gene at $12 \mathrm{q} 24$. There is no cytogenetic evidence at hand, however, pointing to the actual existence of these potential cytogenetic ways of obtaining HMGA2 rearrangements in connective tissue tumors.
This notwithstanding, many chromosomal rearrangements, such as balanced and unbalanced translocations, inversions, insertions, and deletions involving band $12 \mathrm{q} 14$ and targeting the HMGA2 gene have repeatedly been reported in lipomas and other benign neoplasms of connective tissues (40). In most cases, HMGA2 fuses out-of-frame with the 3'-end partner gene or with intergenic sequences $(32,34,36,41-53)$. In these fusions, the part of the HMGA2 gene coding for the AT-hook domains, i.e., exons 1 to 3 , is separated from the 3'-untranslated region which regulates $H M G A 2$ transcription, resulting in expression and translation of a tumorigenic, truncated form of HMGA2 (54-60). Thus, the addition of ectopic fusion sequences does not seem to have any significant impact compared with the tumorigenic properties of truncated HMGA2 (61).

In some cases, the chromosomal rearrangements result in an $H M G A 2$ fusion with in-frame transcripts coding for chimeric HMGA2 proteins. The chromosomal translocation $\mathrm{t}(3 ; 12)(\mathrm{q} 28 ; \mathrm{q} 14)$ repeatedly found in lipomas (especially) but also chondroid hamartomas and chondromas, fuses in-frame HMGA2 with a gene whose official full name is LIM domaincontaining preferred translocation partner in lipoma ( $L P P)$ (47, 62-68). The resulting chimera codes for an HMGA2LPP protein containing the AT-hook domains of HMGA2 and the LIM domains of the LPP protein $(47,62-70)$.

Fusion of $H M G A 2$ with epidermal growth factor receptor gene $(E G F R)$ from $7 \mathrm{p} 11$ gives rise to a fusion gene which encodes a chimeric HMGA2-EGFR protein; this was reported in a single case of glioblastoma (71). An in-frame fusion transcript of HMGA2 with Yes1-associated transcriptional regulator gene $(Y A P 1)$ from $11 \mathrm{q} 22$ was reported in an aggressive angiomyxoma (72).

Each of the above-mentioned partners is involved in different cell functions and all have been implicated in tumor development. LPP belongs to the zyxin family of LIM domain proteins, has focal adhesion capacity, is a transcription activator, interacts with various proteins through its numerous protein-protein interactions domains, and is known to play a role in many biological and cellular processes $(69,73-75)$. In a secondary acute myeloid leukemia with a $\mathrm{t}(3 ; 11)(\mathrm{q} 28 ; \mathrm{q} 23)$ chromosomal translocation, LPP fused to lysine methyltransferase 2A (KMT2A, formerly $M L L)$ generating a $K M T 2 A-L P P$ fusion gene which codes for a chimeric protein containing the AT hook of KMT2A and the LIM domains of LPP (76). LPP was found to be involved in tumor cell migration, invasion, and metastasis (75). EGFR is a transmembrane glycoprotein, a member of the protein kinase superfamily, and a receptor for members of the EGF family (77). Mutation and amplification/overexpression of EGFR and its protein have been reported in lung cancer and brain tumors (77). YAP1 is a transcriptional co-activator which affects the Hippo signaling pathway (78-80). Mutations, amplifications, and fusion genes of $Y A P 1$ have been reported in various types of cancer (78-80). 
Table IV. Confirmation of fusion junction of the high-mobility group AT-hook 2 and nuclear receptor co-repressor 2 (HMGA2-NCOR2) chimeric transcript using the "grep" command line utility with the search term "AGGAAATGGCAGCAGCAA" and "AGGAAATGGCAGCAACAA" for case 1 and "CCTGCTCAGCAGCAGCAA" and "CCTGCTCAGCAGCACAA" for case 2. The data show that there was an in-frame insertion/deletion of a CAG triplet in exon 16 of NCOR2 at the junction of fusion transcripts. The sequence of NCOR2 is shown in bold italics.

\begin{tabular}{ll}
\hline Case & Grep search term \\
\hline 1 & AGGAAATGGCAGCAGCAA
\end{tabular}

\section{AGGAAATGGCAGCAACAA}

Sequences

AAAACGGCCAAGAGGCAGACCTAGGAAATGGCAGCAGCAACAACAGCAGCAG CAGCAGCAGCAGCAGCAGCAGCAGAGAAAAACGGCCAAGAGGCAGACCT AGGAAATGGCAGCAGCAACAACAGCAGCAGCAGCAGCAGCAGCAGCAG CAGAGGCAGACCTAGGAAATGGCAGCAGCAACAACAGCAGCAGCAGCAG CAGCAGCAGCAGCAGCAGCAGCAGCCCATGCGGCCAAGAGGCAGACCTA

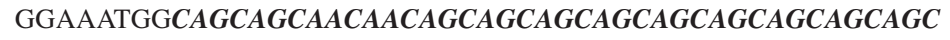
AGCAGCAGCGAAAAACGGCCAAGAGGCAGACCTAGGAAATGGCAGCAG CAACAACAGCAGCAGCAGCATCAGCAGCAACAGCAGCGACCTAGGAAATG

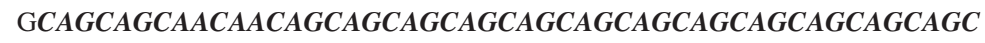
AGCCCATGCCCCGGCAGAAGCCACTGGAGAAAAACGGCCAAGAGGCAGA CCTAGGAAATGGCAGCAGCAACAACAGCAGCAGCAGCAGCGCCAAGAGGC

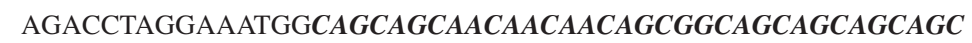
AGCAGCAGCAGCAGCAGTGGAGAAAAACGGCCAAGAGGCAGACCTAGG

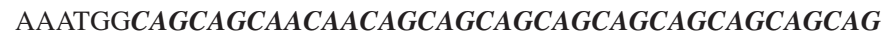
AAACGGCCAAGAGGCAGACCTAGGAAATGGCAGCAACAACAGCAGCAGCA GCAGCAGCAGCAGCAGCAGCAGCAGCAAAGAAAGCAGAAGCCACTGGAGA AAAACGGCCAAGAGGCAGACCTAGGAAATGGCAGCAACAACAGCAGCAGCAG AGAAAAACGGCCAAGAGGCAGACCTAGGAAATGGCAGCAACAACAGCAGCAG CAGCAGCAGCAGCAGCAGCAGCAGAGGAAATGGCAGCAACAACAGCAGCAGC AGCAGCAGCAGCAGCAGCAGCAGCAGCAGCCCATGCCCCGCAGCAGCCAG

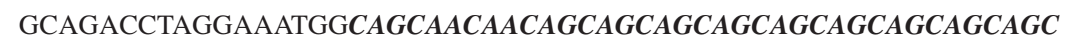
AGCAGCAGCAGCCCATGCCCCAAAAGAAAGCAGAAGCCACTGGAGAAAAACGGC

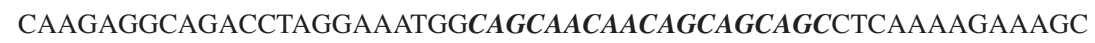
AGAAGCCACTGGAGAAAAACGGCCAAGAGGCAGACCTAGGAAATGGCAGCAACAA CAGCAGCACTGGAGAAAAACGGCCAAGAGGCAGACCTAGGAAATGGCAGCAACAAC

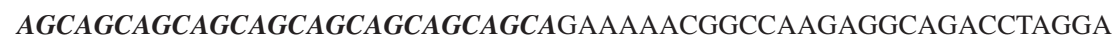

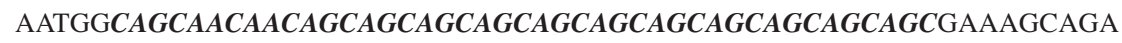
AGCCACTGGAGAAAAACGGCCAAGAGGCAGACCTAGGAAATGGCAGCAACAACAGCA

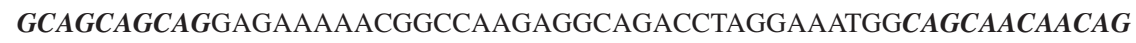

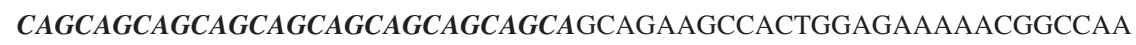

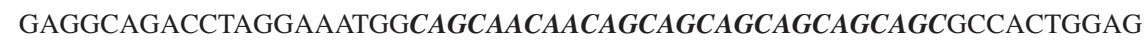
AAAAACGGCCAAGAGGCAGACCTAGGAAATGGCAGCAACAACAGCAGCAGCAGCAGCA GCAGCAGCGCTCAAAAGAAAGCAGAAGCCACTGGAGAAAAACGGCCAAGAGGCAGA CCTAGGAAATGGCAGCAACAACAGCAGCGGCAGACCTAGGAAATGGCAGCAA

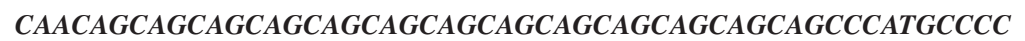

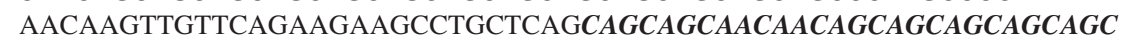

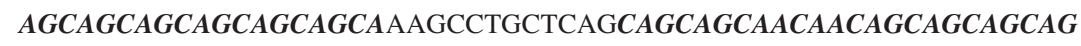

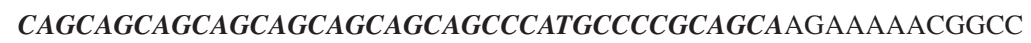
AAGAGGCAGACCTAGGAAATGGCCACAACAAGTTGTTCAGAAGAAGCCTGCTC AGCAGCAGCAAAGAAGCCTGCTCAGCAGCAGCAACAACAGCAGCAGCAGCAGC AGCAGCAGCAGCAGCAGCAGCAGCCCATGCCCCGAGTTGTTCAGAAGAAGCCTG

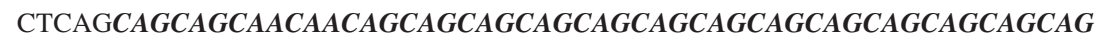
ATGGCCACAACAAGTTGTTCAGAAGAAGCCTGCTCAGCAGCAGCAACAACAGC

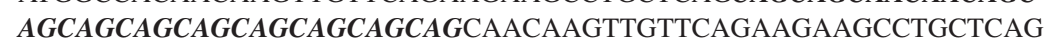
CAGCAGCAACAACAACAGCAGCAGCAGCAGCAGCAGCAGCAGCAGCCAGACCTA GGAAATGGCCACAACAAGTTGTTCAGAAGAAGCCTGCTCAGCAGCAGCAACAAC

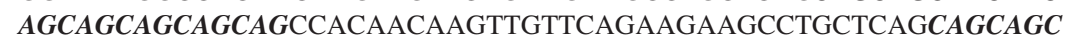

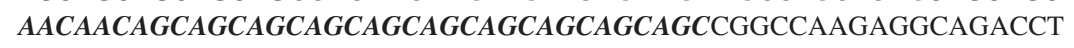
AGGAAATGGCCACAACAAGTTGTTCAGAAGAAGCCTGCTCAGCAGCAGCAACAAC

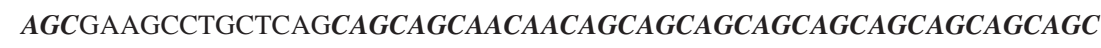

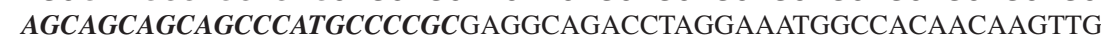
TTCAGAAGAAGCCTGCTCAGCAGCAGCAACAACAGCAGCAGCAGCCACAACAAGTT

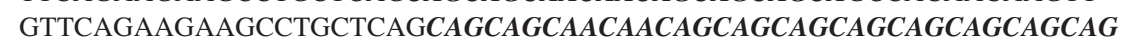
CAGCAGGGCAGACCTAGGAAATGGCCACAACAAGTTGTTCAGAAGAAGCCTGCTCAG 
Table IV. Continued

\begin{tabular}{|c|c|c|}
\hline Case & Grep search term & Sequences \\
\hline & ССТGCTCAGCAGCAACAA & 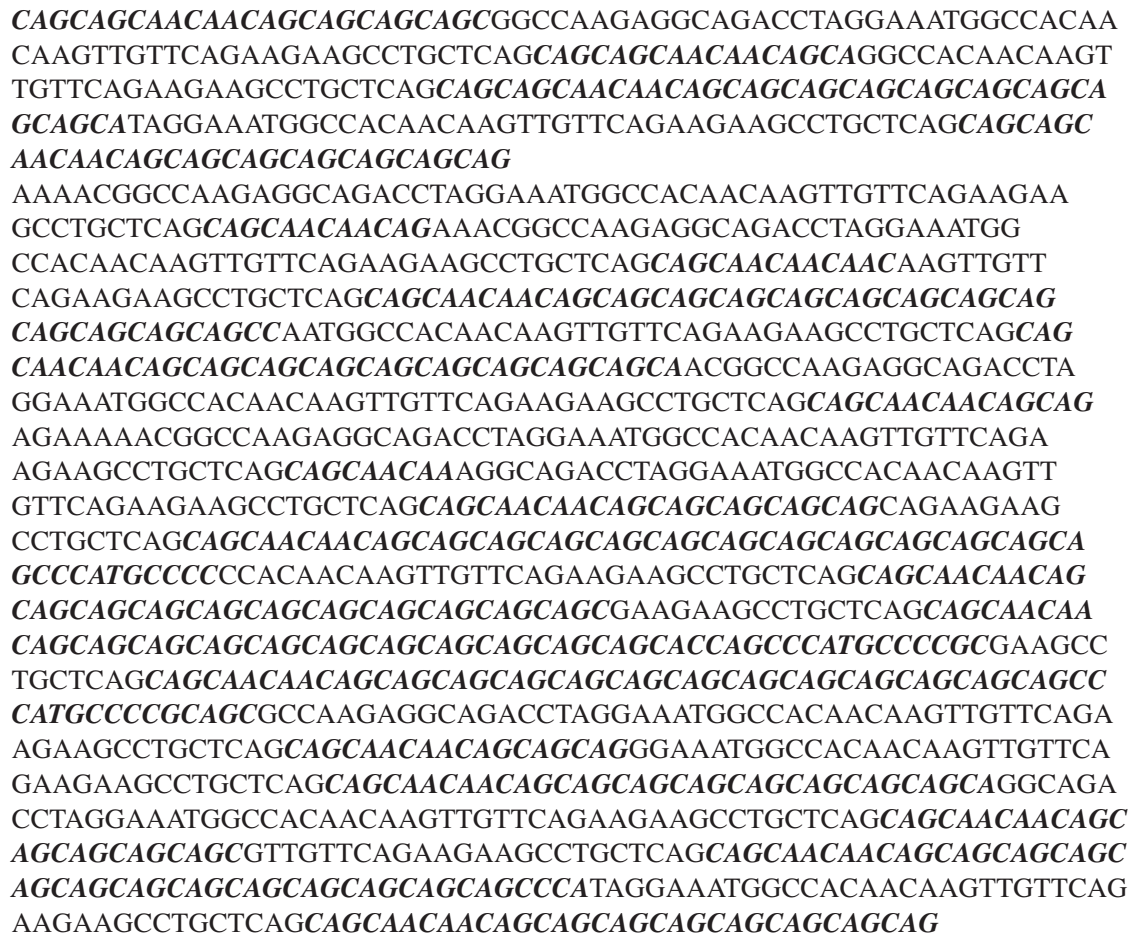 \\
\hline
\end{tabular}

Tumorigenic properties were found for the HMGA2-LPP and HMGA2-EGFR fusion proteins, whereas functional studies have not been performed to test for effects of the HMGA2-YAP1 chimera (54, 70-72). HMGA2-LPP transforms 3T3 mouse embryonic fibroblasts (54). HMGA2LPP was also found to act as a transcription activator stimulated by co-expression of HMGA2 (70). Furthermore, it was shown that through the AT-hook DNA-binding domains of HMGA2, HMGA2-LPP transactivates the promoter of collagen type XI alpha 2 chain (COL11A2) gene and, consequently, promotes chondrogenesis (81).

The HMGA2-EGFR chimeric protein, which contains the AT-hook domains of HMGA2 and transmembrane and kinase domains of EGFR, showed transforming potential, significantly enhancing colony formation in soft agar (71). Implantation of cells expressing HMGA2-EGFR into mice resulted in accelerated tumor growth (71).

The HMGA2-NCOR2 chimeric gene we describe here is the fourth fusion coding for a chimeric protein. Based on the HMGA2 reference sequences NM_003483.4/NP_003474.1 and the NCOR2 reference sequences NM_006312.6/NP_006303.4, the HMGA2-NCOR2 fusion transcripts would code for chimeric proteins composed of the first 83 amino acid residues of HMGA2 (or the first 93 amino acids encoded by the
HMGA2 exon 4-NCOR2 exon 16 fusion) and the last 2021 amino acids of NCOR2 protein (amino acids 494-2514 in NP_006303.4). The chimeric HMGA2-NCOR2 protein thus contains the three regions of HMGA2 (AT-hooks) which bind to the minor groove of adenine-thymine (AT)-rich DNA: AThook 1 between amino acid residues 24-34, AT-hook 2 between amino acid residues 44-54, and AT-hook 3 between amino acid residues 71-82 (82-84). It would also contain all functional and interaction domains of NCOR2 except the first $\mathrm{N}$-terminal repressor domain (RD1) and the deacetylase activation domain (absence of NCOR2 amino acid residues 1-493). Thus, it contains the histone interaction domain, the RD2 and RD3 repressor domains, the two nuclear receptor interaction domains, and RID1 and RID2 (85-87).

While we were working on the present project, a publication appeared reporting the finding of an HMGA2NCOR2 fusion gene in six giant cell-rich soft tissue tumors which expressed low- to high-molecular-weight keratins (the tumor cells stained positively with the immunohistochemical marker cytokeratin AE1/AE3, which is a mixture of two different clones of monoclonal antibodies to cytokeratin AE1 and AE3) (88). In four of the tumors, exon 3 of HMGA2 fused to exon 16 of $N C O R 2$, i.e., the fusion transcript was identical to that found by us in case 1 . In the other two 


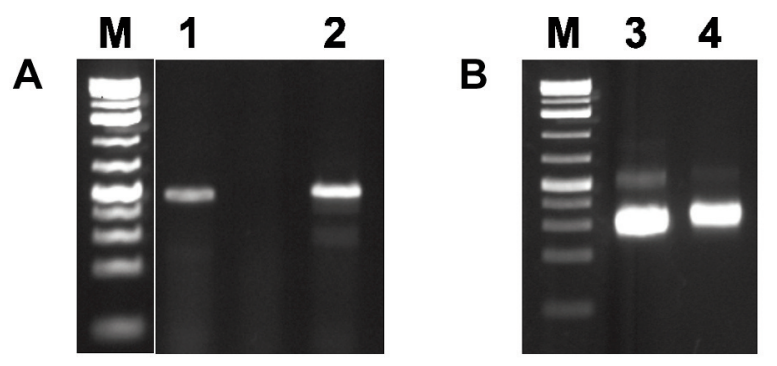

C

$\begin{array}{ll:c}\text { Cases } 1 \text { and } 6 & \text { HMGA2 exon } 3 & \text { NCOR2 exon } 16 \\ \text { G AG G CA G AC C TAG G AAAT G GA G CAR CAACAR CA G CA G CA }\end{array}$

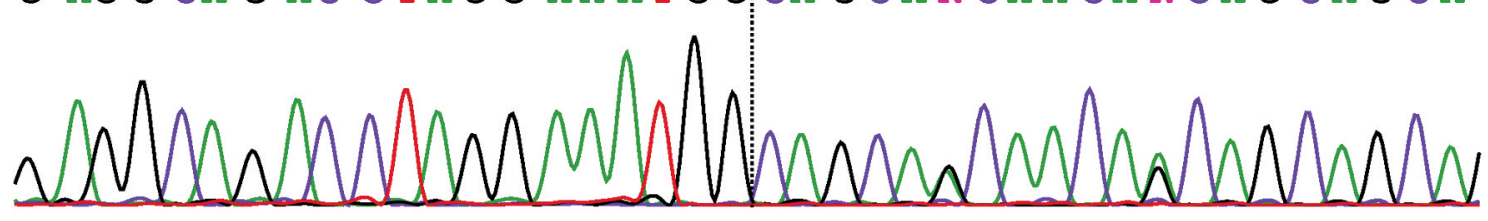

Case 2 HMGA2 exon $4:$ NCOR2 exon 16

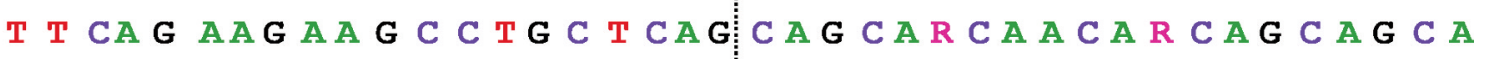
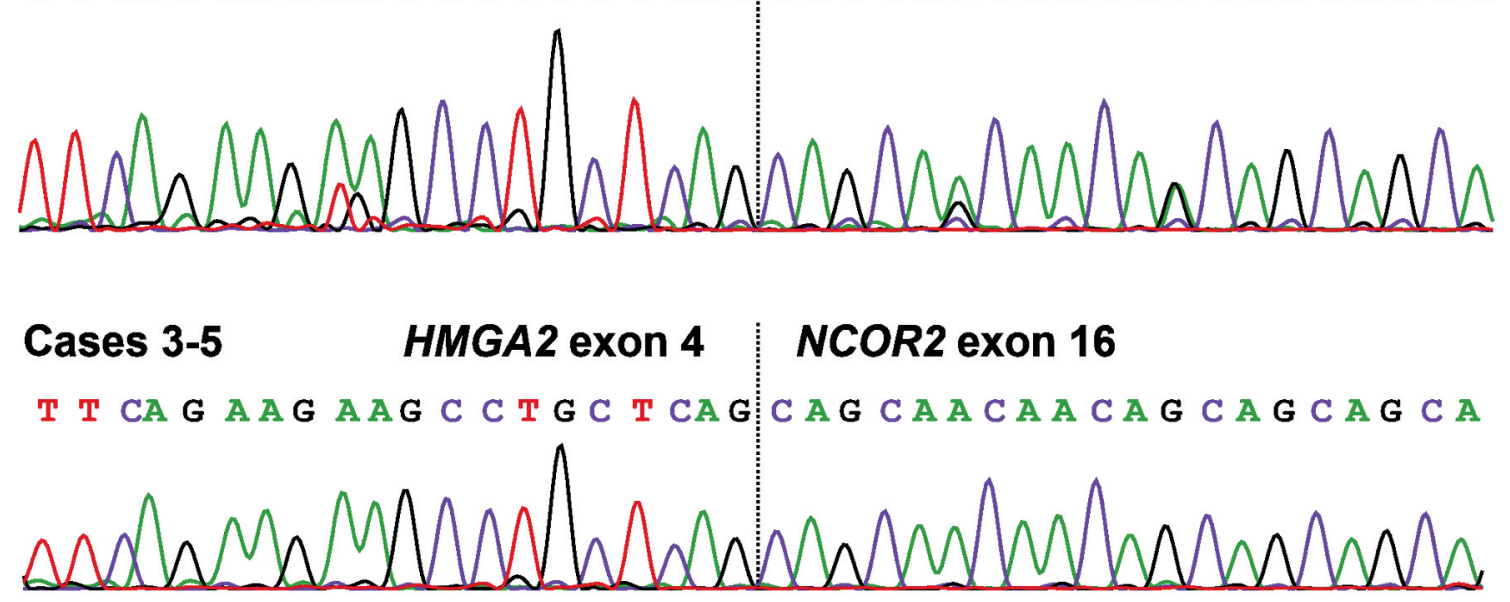

Figure 4. Reverse transcription polymerase chain reaction (PCR) and Sanger sequencing of the osteoclastic giant cell-rich tumors of bone. A: Gel electrophoresis showing amplified high-mobility group AT-hook 2 and nuclear receptor co-repressor 2 fusion (HMGA2-NCOR2) cDNA fragments using the outer primer combination HMGA2-846F1/NCOR2-2127R1 for cases 1 (lane 1) and 2 (lane 2). B; Gel electrophoresis showing amplified HMGA2-NCOR2 cDNA fragments with nested PCR using the inner primer combination HMGA2-925F1/NCOR2-2076R1 for cases 1 (lane 3) and 2 (lane 4). M: GeneRuler $1 \mathrm{~kb}$ Plus DNA ladder (ThermoFisher Scientific). C: Partial sequence chromatograms of cDNA amplified fragments from cases 1 and 6, case 2, and cases 3-5 showing the junction between HMGA2 and NCOR2. In cases 1 and 6, exon 3 of HMGA2 was fused to exon 16 of NCOR2. In cases 2 to 5, exon 4 of HMGA2 was fused to exon 16 of NCOR2. In cases 1, 2, and 6, there was an in-frame insertion/deletion of a CAG triplet in exon 16 of NCOR2 at the junction of the fusion transcripts. For this reason, the NCOR2 sequence at the junction is CAGCARCAACARCAGCAGCA. The letter $R$ in exon 16 of NCOR2 indicates nucleotide $G$ or A.

tumors, exon 3 of HMGA2 fused in-frame to exon 20 of NCOR2 (88). Thus, both studies, the present and that published by Agaimy and coworkers (88), showed HMGA2$N C O R 2$ fusion genes coding for similar chimeric proteins and that a group of giant cell-rich tumors of bone or soft tissue are characterized by the HMGA2-NCOR2 fusion gene. Our study, furthermore, presents the first cytogenetic evidence, also obtained by FISH analyses, of this fusion. 


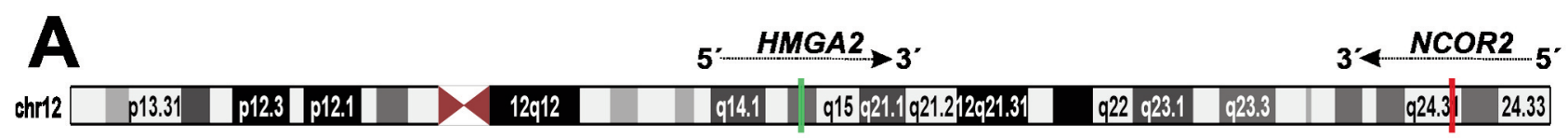

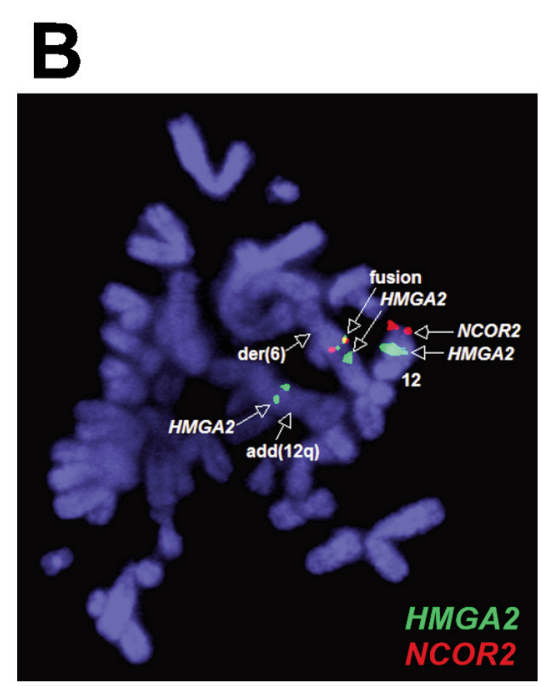

Case 2

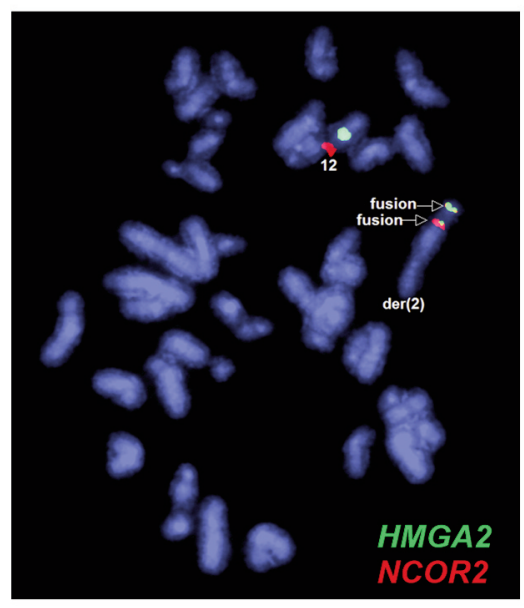

Case 4

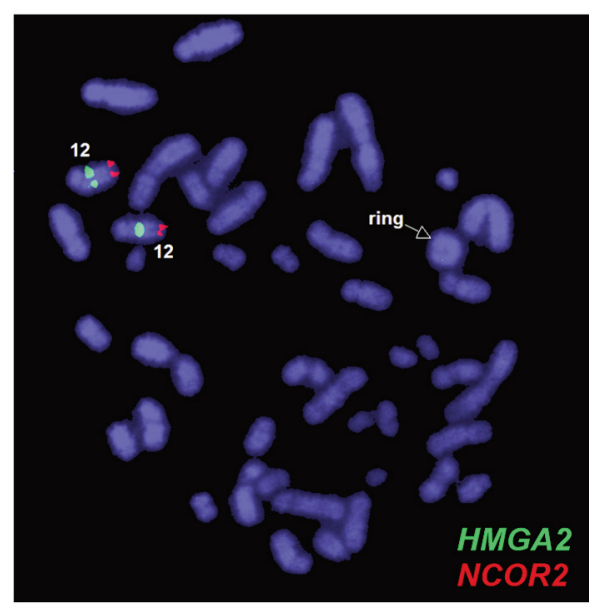

Case 5

Figure 5. Fluorescence in situ hybridization (FISH) analysis of osteoclastic giant cell-rich tumors of bone using double-fusion FISH probes. A: The position and the orientation of transcription (5'-> 3') of the high-mobility group AT-hook 2 (HMGA2; green label) and nuclear receptor co-repressor 2 (NCOR2; red label) genes are shown on the ideogram of chromosome 12. B: FISH results on metaphase spreads from cases 2, 4, and 5. The probes for HMGA2 were labelled with fluorescein-12-dCTP to obtain green signals. The probes for NCOR2 were labelled with Texas Red-5-dCTP to obtain a red signal. Case 2: A yellow signal for HMGA2-NCOR2 fusion together with a green signal for HMGA2 were detected on the der(6)(6pter$>6 q 21:: 12 q 13->12 q ?:: ?: \because 12 q 24->12 q 14:)$. Green signals for HMGA2 were found on chromosomes 12 and add(12)(q13). A red signal for NCOR2 was found on chromosome 12. Case 4: Two fusion signals were found on der(2)(2pter->2q37::12q24->12q14:) together with a green signal for HMGA2 and a red signal for NCOR2 on chromosome 12. Case 5: A metaphase spread with ring chromosome showing green (HMGA2) and red (NCOR2) signals on the two chromosomes 12 indicating that the HMGA2-NCOR2 fusion must have been formed in another, undetected cytogenetic clone.

An in-frame HMGA2-NCOR2 fusion transcript was also reported in a tenosynovial giant-cell tumor without any information on the fusion junction (89). However, the data indicate that the HMGA2-NCOR2 pathogenetic pathway might also be found in other types of neoplasia.

The tumors with $H M G A 2-N C O R 2$ of the present study belonged to the group of osteoclastic giant cell-rich tumors; they were initially diagnosed as giant cell tumors of bone negative for $\mathrm{H} 3.3 \mathrm{G} 35 \mathrm{~W}(1,2)$ and difficult to distinguish from non-ossifying fibromas. We believe that the HMGA2NCOR2 fusion transcript can be used as a differential diagnostic marker useful in subdividing various osteoclastic giant cell-rich tumors.

\section{Conflicts of Interest}

The Authors declare that they have no potential conflicts of interest in regard to this study.

\section{Authors' Contributions}

IP designed and supervised the research, performed molecular genetic experiments and bioinformatics analysis, and wrote the article. LG performed cytogenetic analysis. KA performed cytogenetic analysis, molecular genetic experiments, and evaluated the data. ML-I performed pathological examination. IL performed pathological examination. SH evaluated the cytogenetic data and assisted in writing the article. All authors read and approved of the final article.

\section{Acknowledgements}

This work was supported by grants from Radiumhospitalets Legater.

\section{References}

1 WHO Classification of Tumours Editorial Board: WHO classification of Tumours of Soft Tissue and Bone. Fifth Edition. Lyon, France, International Agency for Research on Cancer, 2020. 
2 Choi JH and Ro JY: The 2020 WHO classification of tumors of bone: an updated review. Adv Anat Pathol 28(3): 119-138, 2021. PMID: 33480599. DOI: 10.1097/PAP.0000000000000293

3 Oliveira AM, Hsi BL, Weremowicz S, Rosenberg AE, Dal Cin P, Joseph N, Bridge JA, Perez-Atayde AR and Fletcher JA: USP6 (Tre2) fusion oncogenes in aneurysmal bone cyst. Cancer Res 64(6): 1920-1923, 2004. PMID: 15026324. DOI: 10.1158/0008-5472.can-03-2827

4 Oliveira AM, Perez-Atayde AR, Inwards CY, Medeiros F, Derr V, Hsi BL, Gebhardt MC, Rosenberg AE and Fletcher JA: USP6 and $C D H 11$ oncogenes identify the neoplastic cell in primary aneurysmal bone cysts and are absent in so-called secondary aneurysmal bone cysts. Am J Pathol 165(5): 1773-1780, 2004. PMID: 15509545. DOI: 10.1016/S0002-9440(10)63432-3

5 Oliveira AM, Perez-Atayde AR, Dal Cin P, Gebhardt MC, Chen CJ, Neff JR, Demetri GD, Rosenberg AE, Bridge JA and Fletcher JA: Aneurysmal bone cyst variant translocations upregulate USP6 transcription by promoter swapping with the ZNF9, COL1A1, TRAP150, and OMD genes. Oncogene 24(21): 3419-3426, 2005. PMID: 15735689 . DOI: $10.1038 /$ sj.onc.1208506

6 Šekoranja D, Boštjančič E, Salapura V, Mavčič B and Pižem J: Primary aneurysmal bone cyst with a novel SPARC-USP6 translocation identified by next-generation sequencing. Cancer Genet 228-229: 12-16, 2018. PMID: 30553465. DOI: 10.1016/j.cancergen.2018.07.001

7 Panagopoulos I, Gorunova L, Andersen K, Lobmaier I, LundIversen M, Micci F and Heim S: Fusion of the lumican (LUM) gene with the ubiquitin specific peptidase 6 (USP6) gene in an aneurysmal bone cyst carrying a $\mathrm{t}(12 ; 17)(\mathrm{q} 21 ; \mathrm{p} 13)$ chromosome translocation. Cancer Genomics Proteomics 17(5): 555-561, 2020. PMID: 32859633. DOI: 10.21873/cgp.20211

8 Šekoranja D, Zupan A, Mavčič B, Martinčič D, Salapura V, Snoj Ž, Limpel Novak AK and Pižem J: Novel ASAP1-USP6, FAT1USP6, SAR1A-USP6, and TNC-USP6 fusions in primary aneurysmal bone cyst. Genes Chromosomes Cancer 59(6): 357365, 2020. PMID: 32011035. DOI: 10.1002/gcc.22836

9 Panoutsakopoulos G, Pandis N, Kyriazoglou I, Gustafson P, Mertens $\mathrm{F}$ and Mandahl N: Recurrent $\mathrm{t}(16 ; 17)(\mathrm{q} 22 ; \mathrm{p} 13)$ in aneurysmal bone cysts. Genes Chromosomes Cancer 26(3): 265266, 1999. PMID: 10502326. DOI: 10.1002/(sici)10982264(199911)26:3<265::aid-gcc12>3.0.co;2-\#

10 Baumhoer D, Kovac M, Sperveslage J, Ameline B, Strobl AC, Krause A, Trautmann M, Wardelmann E, Nathrath M, Höller S, Hardes J, Gosheger G, Krieg AH, Vieth V, Tirabosco R, Amary F, Flanagan AM and Hartmann W: Activating mutations in the MAP-kinase pathway define non-ossifying fibroma of bone. J Pathol 248(1): 116-122, 2019. PMID: 30549028. DOI: 10.1002/path.5216

11 Bovée JV and Hogendoorn PC: Non-ossifying fibroma: A RASMAPK driven benign bone neoplasm. J Pathol 248(2): 127-130, 2019. PMID: 30809793. DOI: 10.1002/path.5259

12 Behjati S, Tarpey PS, Presneau N, Scheipl S, Pillay N, Van Loo P, Wedge DC, Cooke SL, Gundem G, Davies H, Nik-Zainal S, Martin S, McLaren S, Goodie V, Robinson B, Butler A, Teague JW, Halai D, Khatri B, Myklebost O, Baumhoer D, Jundt G, Hamoudi R, Tirabosco R, Amary MF, Futreal PA, Stratton MR, Campbell PJ and Flanagan AM: Distinct $H 3 F 3 A$ and $H 3 F 3 B$ driver mutations define chondroblastoma and giant cell tumor of bone. Nat Genet 45(12): 1479-1482, 2013. PMID: 24162739. DOI: $10.1038 / \mathrm{ng} .2814$
13 Cleven AH, Höcker S, Briaire-de Bruijn I, Szuhai K, CletonJansen AM and Bovée JV: Mutation analysis of H3F3A and $H 3 F 3 B$ as a diagnostic tool for giant cell tumor of bone and chondroblastoma. Am J Surg Pathol 39(11): 1576-1583, 2015. PMID: 26457357. DOI: 10.1097/PAS.0000000000000512

14 Presneau N, Baumhoer D, Behjati S, Pillay N, Tarpey P, Campbell PJ, Jundt G, Hamoudi R, Wedge DC, Loo PV, Hassan AB, Khatri B, Ye H, Tirabosco R, Amary MF and Flanagan AM: Diagnostic value of $H 3 F 3 A$ mutations in giant cell tumour of bone compared to osteoclast-rich mimics. J Pathol Clin Res 1(2): 113-123, 2015. PMID: 27499898. DOI: 10.1002/cjp2.13

15 Kervarrec T, Collin C, Larousserie F, Bouvier C, Aubert S, Gomez-Brouchet A, Marie B, Miquelestorena-Standley E, Le Nail LR, Avril P, Christophe Pagès J and de Pinieux G: H3F3 mutation status of giant cell tumors of the bone, chondroblastomas and their mimics: a combined high resolution melting and pyrosequencing approach. Mod Pathol 30(3): 393406, 2017. PMID: 28059095. DOI: 10.1038/modpathol.2016.212

16 Ogura K, Hosoda F, Nakamura H, Hama N, Totoki Y, Yoshida A, Ohashi S, Rokutan H, Takai E, Yachida S, Kawai A, Tanaka $\mathrm{S}$ and Shibata T: Highly recurrent H3F3A mutations with additional epigenetic regulator alterations in giant cell tumor of bone. Genes Chromosomes Cancer 56(10): 711-718, 2017. PMID: 28545165. DOI: $10.1002 / \mathrm{gcc} .22469$

17 Righi A, Mancini I, Gambarotti M, Picci P, Gamberi G, Marraccini C, Dei Tos AP, Simi L, Pinzani P and Franchi A: Histone 3.3 mutations in giant cell tumor and giant cell-rich sarcomas of bone. Hum Pathol 68: 128-135, 2017. PMID: 28899740. DOI: 10.1016/j.humpath.2017.08.033

18 Gamberi G, Morandi L, Benini S, Resca A, Cocchi S, Magagnoli G, Donati DM, Righi A and Gambarotti M: Detection of H3F3A p.G35W and p.G35R in giant cell tumor of bone by Allele Specific Locked Nucleic Acid quantitative PCR (ASLNAqPCR). Pathol Res Pract 214(1): 89-94, 2018. PMID: 29254795. DOI: 10.1016/j.prp.2017.10.023

19 Leske H, Rushing E, Budka H, Niehusmann P, Pahnke J and Panagopoulos I: K27/G34 versus K28/G35 in histone H3-mutant gliomas: A note of caution. Acta Neuropathol 136(1): 175-176, 2018. PMID: 29766298. DOI: 10.1007/s00401-018-1867-2

20 Leske H, Dalgleish R, Lazar AJ, Reifenberger G and Cree IA: A common classification framework for histone sequence alterations in tumours: an expert consensus proposal. J Pathol 254(2): 109120, 2021. PMID: 33779999. DOI: 10.1002/path.5666

21 Panagopoulos I, Gorunova L, Lund-Iversen M, Andersen K, Andersen HK, Lobmaier I, Bjerkehagen B and Heim S: Cytogenetics of spindle cell/pleomorphic lipomas: Karyotyping and FISH analysis of 31 tumors. Cancer Genomics Proteomics 15(3): 193-200, 2018. PMID: 29695401. DOI: $10.21873 /$ cgp. 20077

22 Mandahl N: Methods in solid tumour cytogenetics. In: Human Cytogenetics: Malignancy and Acquired Abnormalities. Rooney DE (ed.). New York, Oxford University Press, pp. 165-203, 2001.

23 McGowan-Jordan J, Simons A and Schmid M: ISCN 2016: An International System for Human Cytogenomic Nomenclature. Basel, Karger, pp. 140, 2016.

24 Kangaspeska S, Hultsch S, Edgren H, Nicorici D, Murumägi A and Kallioniemi O: Reanalysis of RNA-sequencing data reveals several additional fusion genes with multiple isoforms. PLoS One 7(10): e48745, 2012. PMID: 23119097. DOI: 10.1371/journal. pone. 0048745 
25 Nicorici D, Satalan M, Edgren H, Kangaspeska S, Murumagi A, Kallioniemi O, Virtanen S and Kilkku O: FusionCatcher - a tool for finding somatic fusion genes in paired-end RNA-sequencing data. bioRxiv, 2014. DOI: 10.1101/011650

26 Panagopoulos I, Torkildsen S, Gorunova L, Tierens A, Tjønnfjord GE and Heim S: Comparison between karyotypingFISH-reverse transcription PCR and RNA-sequencing-fusion gene identification programs in the detection of KAT6ACREBBP in acute myeloid leukemia. PLoS One 9(5): e96570, 2014. PMID: 24798186. DOI: 10.1371/journal.pone.0096570

27 Panagopoulos I, Gorunova L, Bjerkehagen B and Heim S: The "grep" command but not FusionMap, FusionFinder or ChimeraScan captures the CIC-DUX4 fusion gene from whole transcriptome sequencing data on a small round cell tumor with $\mathrm{t}(4 ; 19)(\mathrm{q} 35 ; \mathrm{q} 13)$. PLoS One 9(6): e99439, 2014. PMID: 24950227. DOI: 10.1371/journal.pone.0099439

28 Panagopoulos I, Gorunova L, Bjerkehagen B and Heim S: Novel KAT6B-KANSL1 fusion gene identified by RNA sequencing in retroperitoneal leiomyoma with $\mathrm{t}(10 ; 17)(\mathrm{q} 22 ; \mathrm{q} 21)$. PLoS One 10(1): e0117010, 2015. PMID: 25621995. DOI: 10.1371/ journal.pone. 0117010

29 Panagopoulos I, Gorunova L, Lund-Iversen M, Bassarova A and Heim S: Fusion of the genes PHF1 and TFE3 in malignant chondroid syringoma. Cancer Genomics Proteomics 16(5): 345 351, 2019. PMID: 31467228. DOI: $10.21873 / \mathrm{cgp} .20139$

30 Panagopoulos I, Gorunova L, Andersen K, Lund-Iversen M, Lobmaier I, Micci F and Heim S: NDRG1-PLAG1 and TRPS1PLAG1 fusion genes in chondroid syringoma. Cancer Genomics Proteomics 17(3): 237-248, 2020. PMID: 32345665. DOI: $10.21873 / \mathrm{cgp} .20184$

31 Altschul SF, Gish W, Miller W, Myers EW and Lipman DJ: Basic local alignment search tool. J Mol Biol 215(3): 403-410, 1990. PMID: 2231712. DOI: 10.1016/S0022-2836(05)80360-2

32 Panagopoulos I, Bjerkehagen B, Gorunova L, Taksdal I and Heim S: Rearrangement of chromosome bands 12q14 15 causing HMGA2-SOX5 gene fusion and HMGA2 expression in extraskeletal osteochondroma. Oncol Rep 34(2): 577-584, 2015 PMID: 26043835. DOI: 10.3892/or.2015.4035

33 Pandis N, Bardi G, Sfikas K, Panayotopoulos N, Tserkezoglou $\mathrm{A}$ and Fotiou S: Complex chromosome rearrangements involving 12 q14 in two uterine leiomyomas. Cancer Genet Cytogenet 49(1): 51-56, 1990. PMID: 2397473. DOI: 10.1016/01654608(90)90163-5

34 Kazmierczak B, Hennig Y, Wanschura S, Rogalla P, Bartnitzke $\mathrm{S}$, Van de Ven W and Bullerdiek J: Description of a novel fusion transcript between $H M G I-C$, a gene encoding for a member of the high mobility group proteins, and the mitochondrial aldehyde dehydrogenase gene. Cancer Res 55(24): 6038-6039, 1995. PMID: 8521389.

35 Wanschura S, Dal Cin P, Kazmierczak B, Bartnitzke S, Van den Berghe $\mathrm{H}$ and Bullerdiek $\mathrm{J}$ : Hidden paracentric inversions of chromosome arm $12 \mathrm{q}$ affecting the HMGIC gene. Genes Chromosomes Cancer 18(4): 322-323, 1997. PMID: 9087575.

36 Kazmierczak B, Dal Cin P, Wanschura S, Bartnitzke S, Van den Berghe $\mathrm{H}$ and Bullerdiek J: Cloning and molecular characterization of part of a new gene fused to HMGIC in mesenchymal tumors. Am J Pathol 152(2): 431-435, 1998. PMID: 9466569.

37 Kazmierczak B, Meyer-Bolte K, Tran KH, Wöckel W, Breightman I, Rosigkeit J, Bartnitzke S and Bullerdiek J: A high frequency of tumors with rearrangements of genes of the
$\operatorname{HMGI}(Y)$ family in a series of 191 pulmonary chondroid hamartomas. Genes Chromosomes Cancer 26(2): 125-133, 1999. PMID: 10469450.

38 Weremowicz S and Morton CC: Is HMGIC rearranged due to cryptic paracentric inversion of $12 \mathrm{q}$ in karyotypically normal uterine leiomyomas? Genes Chromosomes Cancer 24(2): 172173, 1999. PMID: 9885987. DOI: 10.1002/(sici)1098-2264(1999 02) $24: 2<172:$ :aid-gcc13>3.0.co;2-z

39 Bartuma H, Panagopoulos I, Collin A, Trombetta D, Domanski HA, Mandahl N and Mertens F: Expression levels of HMGA2 in adipocytic tumors correlate with morphologic and cytogenetic subgroups. Mol Cancer 8: 36, 2009. PMID: 19508721. DOI: $10.1186 / 1476-4598-8-36$

40 Unachukwu U, Chada K and D'Armiento J: High mobility group AT-Hook 2 (HMGA2) oncogenicity in mesenchymal and epithelial neoplasia. Int J Mol Sci 21(9): 3151, 2020. PMID: 32365712. DOI: 10.3390/ijms21093151

41 Geurts JM, Schoenmakers EF, Röijer E, Aström AK, Stenman G and van de Ven WJ: Identification of $N F I B$ as recurrent translocation partner gene of HMGIC in pleomorphic adenomas. Oncogene 16(7): 865-872, 1998. PMID: 9484777. DOI: 10.1038/sj.onc.1201609

42 Mine N, Kurose K, Konishi H, Araki T, Nagai H and Emi M: Fusion of a sequence from HEIIO (14q11) to the HMGIC gene at 12q15 in a uterine leiomyoma. Jpn J Cancer Res 92(2): 135139, 2001. PMID: 11223542. DOI: 10.1111/j.13497006.2001.tb01075.x

43 Broberg K, Zhang M, Strömbeck B, Isaksson M, Nilsson M, Mertens F, Mandahl N and Panagopoulos I: Fusion of RDC1 with $H M G A 2$ in lipomas as the result of chromosome aberrations involving 2q35-37 and 12q13-15. Int J Oncol 21(2): 321-326, 2002. PMID: 12118328.

44 Nilsson M, Panagopoulos I, Mertens F and Mandahl N: Fusion of the HMGA2 and NFIB genes in lipoma. Virchows Arch 447(5): 855-858, 2005. PMID: 16133369. DOI: 10.1007/s00428005-0037-9

45 Odero MD, Grand FH, Iqbal S, Ross F, Roman JP, Vizmanos JL, Andrieux J, Laï JL, Calasanz MJ and Cross NC: Disruption and aberrant expression of $H M G A 2$ as a consequence of diverse chromosomal translocations in myeloid malignancies. Leukemia 19(2): 245-252, 2005. PMID: 15618963. DOI: 10.1038/sj. leu. 2403605

46 Nilsson M, Mertens F, Höglund M, Mandahl $\mathrm{N}$ and Panagopoulos I: Truncation and fusion of $H M G A 2$ in lipomas with rearrangements of $5 \mathrm{q} 32->\mathrm{q} 33$ and $12 \mathrm{q} 14->\mathrm{q} 15$. Cytogenet Genome Res 112(1-2): 60-66, 2006. PMID: 16276091. DOI: $10.1159 / 000087514$

47 Hatano H, Morita T, Ogose A, Hotta T, Kobayashi H, Segawa $\mathrm{H}$, Uchiyama T, Takenouchi $\mathrm{T}$ and Sato T: Clinicopathological features of lipomas with gene fusions involving HMGA2. Anticancer Res 28(1B): 535-538, 2008. PMID: 18383898.

48 Velagaleti GV, Tonk VS, Hakim NM, Wang X, Zhang H, Erickson-Johnson MR, Medeiros F and Oliveira AM: Fusion of HMGA2 to COG5 in uterine leiomyoma. Cancer Genet Cytogenet 202(1): 11-16, 2010. PMID: 20804914. DOI: 10.1016/j.cancergencyto.2010.06.002

49 Martin SE, Sausen M, Joseph A, Kingham BF and Martin ES: Identification of a HMGA2-EFCAB6 gene rearrangement following next-generation sequencing in a patient with a $\mathrm{t}(12 ; 22)(\mathrm{q} 14.3 ; \mathrm{q} 13.2)$ and JAK2V617F-positive myeloproliferative neoplasm. Cancer 
Genet 205(6): 295-303, 2012. PMID: 22749035. DOI: 10.1016/ j.cancergen.2012.03.006

50 Bianchini L, Birtwisle L, Saâda E, Bazin A, Long E, Roussel JF, Michiels JF, Forest F, Dani C, Myklebost O, Birtwisle-Peyrottes I and Pedeutour F: Identification of $P P A P 2 B$ as a novel recurrent translocation partner gene of $H M G A 2$ in lipomas. Genes Chromosomes Cancer 52(6): 580-590, 2013. PMID: 23508853. DOI: $10.1002 / \mathrm{gcc} .22055$

51 Panagopoulos I, Gorunova L, Bjerkehagen B, Lobmaier I and Heim S: The recurrent chromosomal translocation $\mathrm{t}(12 ; 18)(\mathrm{q} 14 \sim 15 ; \mathrm{q} 12 \sim 21)$ causes the fusion gene HMGA2SETBP1 and HMGA2 expression in lipoma and osteochondrolipoma. Int J Oncol 47(3): 884-890, 2015. PMID: 26202160. DOI: $10.3892 /$ ijo.2015.3099

52 Agostini A, Gorunova L, Bjerkehagen B, Lobmaier I, Heim S and Panagopoulos I: Molecular characterization of the $\mathrm{t}(4 ; 12)$ (q27 28;q14 15) chromosomal rearrangement in lipoma. Oncol Lett 12(3): 1701-1704, 2016. PMID: 27588119. DOI: $10.3892 /$ ol.2016.4834

53 Panagopoulos I, Gorunova L, Agostini A, Lobmaier I, Bjerkehagen B and Heim S: Fusion of the HMGA2 and C9orf 92 genes in myolipoma with $\mathrm{t}(9 ; 12)(\mathrm{p} 22 ; \mathrm{q} 14)$. Diagn Pathol 11: 22, 2016. PMID: 26857357. DOI: 10.1186/s13000-016-0472-8

54 Fedele M, Berlingieri MT, Scala S, Chiariotti L, Viglietto G, Rippel V, Bullerdiek J, Santoro M and Fusco A: Truncated and chimeric HMGI-C genes induce neoplastic transformation of NIH3T3 murine fibroblasts. Oncogene 17(4): 413-418, 1998. PMID: 9696033. DOI: 10.1038/sj.onc.1201952

55 Arlotta P, Tai AK, Manfioletti G, Clifford C, Jay G and Ono SJ: Transgenic mice expressing a truncated form of the high mobility group I-C protein develop adiposity and an abnormally high prevalence of lipomas. J Biol Chem 275(19): 14394-14400, 2000. PMID: 10747931. DOI: $10.1074 /$ jbc.m000564200

56 Borrmann L, Wilkening S and Bullerdiek J: The expression of HMGA genes is regulated by their 3'UTR. Oncogene 20(33): 4537-4541, 2001. PMID: 11494149. DOI: 10.1038/sj.onc.1204577

57 Lee YS and Dutta A: The tumor suppressor microRNA let-7 represses the HMGA2 oncogene. Genes Dev 21(9): 1025-1030, 2007. PMID: 17437991. DOI: $10.1101 / \mathrm{gad} .1540407$

58 Mayr C, Hemann MT and Bartel DP: Disrupting the pairing between let-7 and Hmga2 enhances oncogenic transformation. Science 315(5818): 1576-1579, 2007. PMID: 17322030. DOI: $10.1126 /$ science. 1137999

59 Kristjánsdóttir K, Fogarty EA and Grimson A: Systematic analysis of the Hmga2 3' UTR identifies many independent regulatory sequences and a novel interaction between distal sites. RNA 21(7): 1346-1360, 2015. PMID: 25999317. DOI: $10.1261 /$ rna.051177.115

60 Mas A, Cervelló I, Fernández-Álvarez A, Faus A, Díaz A, Burgués O, Casado $\mathrm{M}$ and Simón C: Overexpression of the truncated form of High Mobility Group A proteins (HMGA2) in human myometrial cells induces leiomyoma-like tissue formation. Mol Hum Reprod 21(4): 330-338, 2015. PMID: 25542836. DOI: $10.1093 / \mathrm{molehr} /$ gau114

61 Zaidi MR, Okada Y and Chada KK: Misexpression of full-length HMGA2 induces benign mesenchymal tumors in mice. Cancer Res 66(15): 7453-7459, 2006. PMID: 16885341. DOI: 10.1158/0008-5472.CAN-06-0931

62 Ashar HR, Fejzo MS, Tkachenko A, Zhou X, Fletcher JA, Weremowicz S, Morton CC and Chada K: Disruption of the architectural factor HMGI-C: DNA-binding AT hook motifs fused in lipomas to distinct transcriptional regulatory domains. Cell 82(1): 57-65, 1995. PMID: 7606786. DOI: 10.1016/00928674(95)90052-7

63 Schoenmakers EF, Wanschura S, Mols R, Bullerdiek J, Van den Berghe $\mathrm{H}$ and Van de Ven WJ: Recurrent rearrangements in the high mobility group protein gene, $H M G I-C$, in benign mesenchymal tumours. Nat Genet 10(4): 436-444, 1995. PMID: 7670494. DOI: $10.1038 / n g 0895-436$

64 Rogalla P, Lemke I, Kazmierczak B and Bullerdiek J: An identical HMGIC-LPP fusion transcript is consistently expressed in pulmonary chondroid hamartomas with $\mathrm{t}(3 ; 12)$ (q27-28; $\mathrm{q} 14-$ 15). Genes Chromosomes Cancer 29(4): 363-366, 2000. PMID: 11066083.

65 Dahlén A, Mertens F, Rydholm A, Brosjö O, Wejde J, Mandahl N and Panagopoulos I: Fusion, disruption, and expression of HMGA2 in bone and soft tissue chondromas. Mod Pathol 16(11): 1132-1140, 2003. PMID: 14614053. DOI: 10.1097/01.MP.0000092954.42656.94

66 Kubo T, Matsui Y, Goto T, Yukata K, Endo K, Sato R, Tsutsui T and Yasui N: MRI characteristics of parosteal lipomas associated with the HMGA2-LPP fusion gene. Anticancer Res 26(3B): 2253-2257, 2006. PMID: 16821597.

67 Kubo T, Matsui Y, Naka N, Araki N, Goto T, Yukata K, Endo K, Yasui N, Myoui A, Kawabata $\mathrm{H}$, Yoshikawa $\mathrm{H}$ and Ueda $\mathrm{T}$ : Expression of HMGA2-LPP and $L P P-H M G A 2$ fusion genes in lipoma: identification of a novel type of $L P P-H M G A 2$ transcript in four cases. Anticancer Res 29(6): 2357-2360, 2009. PMID: 19528502.

68 Kubo T, Matsui Y, Naka N, Araki N, Myoui A, Endo K, Yasui N, Ohtani O, Suzuki K, Kimura T, Yoshikawa H and Ueda T: Specificity of fusion genes in adipocytic tumors. Anticancer Res 30(2): 661-664, 2010. PMID: 20332486.

69 Petit MM, Mols R, Schoenmakers EF, Mandahl N and Van de Ven WJ: $L P P$, the preferred fusion partner gene of HMGIC in lipomas, is a novel member of the LIM protein gene family. Genomics 36(1): 118-129, 1996. PMID: 8812423. DOI: 10.1006/geno.1996.0432

70 Crombez KR, Vanoirbeek EM, Van de Ven WJ and Petit MM: Transactivation functions of the tumor-specific HMGA2/LPP fusion protein are augmented by wild-type HMGA2. Mol Cancer Res 3(2): 63-70, 2005. PMID: 15755872. DOI: 10.1158/15417786.MCR-04-0181

71 Komuro A, Raja E, Iwata C, Soda M, Isogaya K, Yuki K, Ino Y, Morikawa M, Todo T, Aburatani H, Suzuki H, Ranjit M, Natsume A, Mukasa A, Saito N, Okada H, Mano H, Miyazono $\mathrm{K}$ and Koinuma D: Identification of a novel fusion gene HMGA2-EGFR in glioblastoma. Int J Cancer 142(8): 1627-1639, 2018. PMID: 29193056. DOI: 10.1002/ijc.31179

72 Lee MY, da Silva B, Ramirez DC and Maki RG: Novel HMGA2YAP1 fusion gene in aggressive angiomyxoma. BMJ Case Rep 12(5): e227475, 2019. PMID: 31142482. DOI: 10.1136/bcr-2018227475

73 Zheng Q and Zhao Y: The diverse biofunctions of LIM domain proteins: determined by subcellular localization and proteinprotein interaction. Biol Cell 99(9): 489-502, 2007. PMID: 17696879. DOI: $10.1042 / B C 20060126$

74 Grunewald TG, Pasedag SM and Butt E: Cell adhesion and transcriptional activity - defining the role of the novel protooncogene LPP. Transl Oncol 2(3): 107-116, 2009. PMID: 19701494. DOI: $10.1593 /$ tlo.09112 
75 Ngan E, Kiepas A, Brown CM and Siegel PM: Emerging roles for LPP in metastatic cancer progression. J Cell Commun Signal 12(1): 143-156, 2018. PMID: 29027626. DOI: 10.1007/s12079017-0415-5

76 Dahéron L, Veinstein A, Brizard F, Drabkin H, Lacotte L, Guilhot F, Larsen CJ, Brizard A and Roche J: Human LPP gene is fused to $M L L$ in a secondary acute leukemia with a $\mathrm{t}(3 ; 11)$ (q28;q23). Genes Chromosomes Cancer 31(4): 382-389, 2001. PMID: 11433529. DOI: $10.1002 / \mathrm{gcc} .1157$

77 Uribe ML, Marrocco I and Yarden Y: EGFR in cancer: Signaling mechanisms, drugs, and acquired resistance. Cancers (Basel) 13(11): 2748, 2021. PMID: 34206026. DOI: 10.3390/cancers 13112748

78 Shibata M, Ham K and Hoque MO: A time for YAP1: Tumorigenesis, immunosuppression and targeted therapy. Int J Cancer 143(9): 2133-2144, 2018. PMID: 29696628. DOI: 10.1002/ijc.31561

79 Thompson BJ: YAP/TAZ: Drivers of tumor growth, metastasis, and resistance to therapy. Bioessays 42(5): e1900162, 2020 PMID: 32128850. DOI: 10.1002/bies.201900162

80 Szulzewsky F, Holland EC and Vasioukhin V: YAP1 and its fusion proteins in cancer initiation, progression and therapeutic resistance. Dev Biol 475: 205-221, 2021. PMID: 33428889. DOI: $10.1016 /$ j.ydbio.2020.12.018

81 Kubo T, Matsui Y, Goto T, Yukata $\mathrm{K}$ and Yasui $\mathrm{N}$ : Overexpression of HMGA2-LPP fusion transcripts promotes expression of the alpha 2 type XI collagen gene. Biochem Biophys Res Commun 340(2): 476-481, 2006. PMID: 16375854 DOI: $10.1016 /$ j.bbrc.2005.12.042

82 Reeves R and Nissen MS: The A.T-DNA-binding domain of mammalian high mobility group I chromosomal proteins. A novel peptide motif for recognizing DNA structure. J Biol Chem 265(15): 8573-8582, 1990. PMID: 1692833.

83 Cattaruzzi G, Altamura S, Tessari MA, Rustighi A, Giancotti V, Pucillo C and Manfioletti G: The second AT-hook of the architectural transcription factor HMGA2 is determinant for nuclear localization and function. Nucleic Acids Res 35(6): 1751-1760, 2007. PMID: 17324944. DOI: 10.1093/nar/gk11106
84 Krahn N, Meier M, To V, Booy EP, McEleney K, O’Neil JD, McKenna SA, Patel TR and Stetefeld J: Nanoscale assembly of high-mobility group AT-Hook 2 protein with DNA replication fork. Biophys J 113(12): 2609-2620, 2017. PMID: 29262356. DOI: $10.1016 /$ j.bpj.2017.10.026

85 Watson PJ, Fairall L and Schwabe JW: Nuclear hormone receptor co-repressors: structure and function. Mol Cell Endocrinol 348(2): 440-449, 2012. PMID: 21925568. DOI: 10.1016/j.mce.2011.08.033

86 Liang N, Jakobsson T, Fan R and Treuter E: The nuclear receptor-co-repressor complex in control of liver metabolism and disease. Front Endocrinol (Lausanne) 10: 411, 2019. PMID: 31293521. DOI: 10.3389/fendo.2019.00411

87 Kang Z and Fan R: PPAR $\alpha$ and NCOR/SMRT corepressor network in liver metabolic regulation. FASEB J 34(7): 87968809, 2020. PMID: 32396271. DOI: 10.1096/fj.202000055RR

88 Agaimy A, Michal M, Stoehr R, Ferrazzi F, Fabian P, Michal M, Franchi A, Haller F, Folpe AL and Kösemehmetoğlu K: Recurrent novel HMGA2-NCOR2 fusions characterize a subset of keratinpositive giant cell-rich soft tissue tumors. Mod Pathol 34(8): 15071520, 2021. PMID: 33742141. DOI: 10.1038/s41379-021-00789-8

89 Brahmi M, Alberti L, Tirode F, Karanian M, Eberst L, Pissaloux $\mathrm{D}$, Cassier P and Blay JY: Complete response to CSF1R inhibitor in a translocation variant of teno-synovial giant cell tumor without genomic alteration of the CSF1 gene. Ann Oncol 29(6): 14881489, 2018. PMID: 29668829. DOI: 10.1093/annonc/mdy 129

Received November 10, 2021

Revised December 9, 2021

Accepted December 10, 2021 